\title{
Gender-oriented statistical discrimination: Aggregate fertility, economic sector, and earnings among young Chinese workers
}

\author{
Jia Wang \\ Department of Sociology, \\ Center for Demography and Ecology \\ University of Wisconsin, Madison \\ and \\ Raymond Sin-Kwok Wong \\ Department of Sociology \\ University of California, Santa Barbara
}

Keywords: Aggregate fertility; Economic sector; Gender earnings inequality; Statistical discrimination; Urban China

Direct all correspondence to Jia Wang (email: jia.wang@wisc.edu), Room 3317, 8128 William H. Sewell Social Sciences Building, 1180 Observatory Drive, Madison, WI 53706-1393, or Raymond Sin-Kwok Wong (email: wong@soc.ucsb.edu), Department of Sociology, Social Sciences \& Media Studies Building, University of California, Santa Barbara, CA 93106-9430. An earlier draft of the paper was presented at the 2015 Research Committee on Social Stratification and Mobility (RC28) summer meeting in Philadelphia. We thank useful comments and suggestions from session participants. The ideas expressed herein are those of the authors. 


\title{
Gender-oriented statistical discrimination: Aggregate fertility, economic sector, and earnings among young Chinese workers
}

\begin{abstract}
Previous studies usually attribute residual gender pay gap net of human capital, job characteristics, and family responsibilities to discrimination against women, without directly exploring the underlying discriminatory mechanisms that generate gender inequalities in the labor market. By applying and extending a previously developed statistical discrimination model to post-socialist urban China, we examine the association between period age-specific fertility rate $(A S F R)$, as a proxy for the likelihood of women taking maternity leave, and the earnings of young working women and men, as well as its variation across economic sectors. Using data compiled from a random sample of the 2005 one-percent mini-census of the People's Republic of China, our analyses reveal gender-asymmetric associations between $A S F R$ and earnings among young workers before their prime fertility age, where $A S F R$ on average was negatively related to the earnings among young women, but not among young men. Moreover, such negative association was limited primarily to female workers in the private sector, negligible in state-owned and collective enterprises, and even reversed to positive among those working in government agencies and public institutions. Our findings suggest that employers in the private sector may use aggregate fertility to "evaluate" potential training and replacement costs and the productivity of female employees associated with maternity leave, thereby reinforcing and perpetuating stereotypes and discrimination against women in the workplace.
\end{abstract}

Keywords: Aggregate fertility; Economic sector; Gender earnings inequality; Statistical discrimination; Urban China 


\section{Introduction}

Although women have achieved enormous improvements in their education, labor force participation, and occupational status over time (DiPrete and Buchmann 2013; Goldin 2006; Van Bavel et al. 2018), they still earn less on average than men with similar characteristics (Blau and Kahn 2017; Charles 2011; England 2010). Such gender pay gap is quite persistent, having lessened only very slightly, if at all, over time. The median monthly gender pay gap for full-time employees is 14.3 percent across OECD countries in 2015, a figure that has barely changed since 2010 and is only about 1 percent lower than a decade earlier (OECD 2017). ${ }^{1}$ Previous studies generally explain the persistent gender pay gap under three theoretical frameworks: human capital (Becker 1985; Mincer and Polachek 1974; Tam 1997), occupational segregation (Bielby 1991; England et al. 1988), and labor market discrimination (Arrow 1971; Becker 1957; Phelps 1972; Reskin 2000). ${ }^{2}$ The last, in particular, argues that women earn less because they are being discriminated against owing to either personal preferences/prejudices (taste-based discrimination) or unfavorable gender stereotypes (information-based discrimination or statistical discrimination) held by their employers and/or coworkers. Empirical support for such gender discrimination is generally established through the residual approach, that is, by attributing unexplained gender differences after statistical control to discrimination, without pinpointing or examining any specific discriminatory mechanisms contributing to gender inequalities in the labor market. ${ }^{3}$ Our understanding about how women are discriminated against and how such discrimination leads to

1 The gender pay gap would be even larger when part-time employees are included, as more women are working part-time with fewer working hours than their male counterparts.

2 This study only examines the process of within-job wage discrimination (Petersen and Morgan 1995) and ignores allocative discrimination - the segregation process of men and women into different occupations/jobs and valuative discrimination - the phenomenon that occupations held primarily by women are paid lower wages than those held primarily by men.

3 This residual approach is related to the traditional definition of discrimination: labor market discrimination exists when there are wage or occupational differences between men and women that are not accounted for by productivity differences (Becker [1957] 1971). It reflects a failure to identify some characteristics of workers that would affect only female workers but have no effect whatsoever on their male counterparts. 
women's lower earnings in the labor market thus remains limited.

In an attempt to directly investigate a specific mechanism of discrimination, Yip and Wong (2014) have quantified one kind of statistical discrimination that potentially contributes to the female-male wage gap in the labor market. Utilizing period age-specific fertility rate $(A S F R)$ as a proxy of young working women's likelihoods to become pregnant and take maternity leave, they found that $A S F R$ had a significant negative impact on female wages, but not on male wages, in the labor market of Hong Kong, a pattern robust against different lagged measures of $A S F R$. Their findings suggest that Hong Kong employers discriminate against women based on aggregate information such as $A S F R$, not individual characteristics, to evaluate the productivity of young working women as lower than comparable male workers. ${ }^{4}$ Their model and results are also consistent with the predictions of social cognitive theory and lend support to the hypothesis of a stereotyping mechanism and evaluation biases as proximate causes of gender inequality in the labor market (Reskin 2000). Despite these insights, their study does not explore the potential variation in the negative impact of period $A S F R$ across workplace and organizations. In fact, the discriminating mechanism involving aggregate fertility and/or other factors is likely to be contextspecific depending on concrete organizational and institutional settings, and investigating such variation has important implications for better understanding gender and labor market inequality under differential structural environment.

To fill this gap, we apply Yip and Wong's gender statistical discrimination model to postsocialist urban China, paying particular attention to the variation in the negative association between period ASFR and young workers' wage across economic sectors. With phenomenal economic growth since the 1990s, post-reform China affords an interesting setting to study this topic because of a surge in gender earnings gap, the formal retreat of some women from the labor force into the domestic sphere, and the continuing salience of economic sector in determining individuals' life chances (Ji et al. 2017; Wu 2013, 2019; Wu and Zhou 2015). Previous studies have found that marketization is a driving force in increasing gender earnings inequality in reformera urban China (He and Wu 2017, 2018; Li C. and Li S. 2008; Wu 2019; Zhang 2004; Zhang J. et al. 2008). As suggested by both academic research and social media, discrimination against

\footnotetext{
${ }^{4}$ In Hong Kong, pregnant female workers are paid during maternity leave whereas fathers
} have no paid paternity leave until recently (Yip and Wong 2014). 
women may play a more prominent role in increasing the gender gap since more and more women have higher educational attainment, especially at the tertiary level (He and Wu 2017; Wu 2019). ${ }^{5}$ However, it is still debatable whether discrimination against women increases or decreases under China's market transition. While some argue that the role of discrimination in gender earnings inequality would become more salient with increasing marketization (Zhang 2004), others claim that the exact opposite would be observed (Liu et al 2000). Unfortunately, all of these studies took the residual approach by attributing unexplained gender earnings gap to discrimination against women, without exploring any specific discriminatory pathways and how such discriminating practice may differ across economic sectors with differential organizational/institutional settings.

Against this backdrop, the current study attempts to answer the following two questions: (1) whether and how period $A S F R$ would be differentially associated with monthly earnings among young men and women in urban China; and (2) whether the (negative) relationship between period $A S F R$ and young workers' earnings would differ across economic sector. Our study sheds new light on gender stratification and inequality research in post-reform urban China and also advances understanding about how labor market discrimination is operating under differential organizational and structural circumstances.

\section{Discrimination and gender employment inequality: Theoretical issues}

Employment discrimination exists when workers with essentially identical productivity experience different outcomes in hiring, wages, career promotion, and other outcomes in the labor market. In general, there are two types of discrimination: taste-based discrimination and statistical (information-based) discrimination. The former occurs when certain workers, such as women and racial minorities, receive lower wages and/or other unequal treatments in the labor market due to the dislikes/prejudices of their employers, co-workers, and customers (Becker [1957] 1971). The latter, on the other hand, is based on informational asymmetries (Aigner and Cain 1977; Arrow 1971, 1972; McCall 1972; Phelps 1972). In real labor markets, when information about the productivity and ability of workers are limited or costly to ascertain, risk-avoiding employers

5 Also see “A Prosperous China Says 'Men Preferred,' and Women Lose.” The New York Times, July 16 ${ }^{\text {th }}$, 2019. https://www.nytimes.com/2019/07/16/world/asia/china-womendiscrimination.html?action=click\&module=Top\%20Stories\&pgtype=Homepage. 
usually make employment decisions based on certain group characteristics of workers - such as race and gender - that are believed to correlate to the expected productivity of workers. Statistical discrimination against a particular group reflects employers' perception of reality rather than individual tastes (Arrow 1971) and persists even when employers are not personally prejudiced. Past empirical studies have demonstrated that statistical discrimination is prevalent and plays a vital role in various labor market inequalities between men and women (Bielby and Baron 1986; Blau and Kahn 2017), among different racial groups (Bertrand and Mullainathan 2004), as well as between immigrants and native-born residents (Rissing and Castilla 2014).

Some sociological studies attempt to explain discrimination against women from the intergroup conflict perspective as an outcome of conflict-based behaviors (e.g., Blumer 1958; Tilly 1998). Given unequal power structure at workplaces, they argue that the dominant group, including employers and/or male coworkers, intentionally discriminates against, excludes, and exploits women as a minority and subordinate group to maintain their own benefits and privileges. While inter-group conflict may well explain some discrimination against women, it is by no means the only or dominant factor. With the passage of anti-discrimination laws in many advanced industrial societies that require "equal pay for equal work" and ban intentional differential treatments by sex, discrimination due to inter-group conflicts is curbed and hence less likely to account for pervasive gender discrimination at the workplace.

In this regard, social cognitive theory offers an alternative understanding. Focusing on proximate causes of discrimination, it postulates that statistical discrimination occurs when employers invoke group stereotypes based on status characteristics like sex and race (Reskin 2000, 2002). For lack of thorough information about individual workers, such stereotyping informs and distorts employers' perceptions, evaluations, and treatment of workers. Relative to men, women are commonly viewed by employers to be less career-oriented, less committed to work, and less productive because of childbirth, childcare, and family responsibilities. These gender stereotypes could occur at any stage during a woman's career that is subject to employers' decisions: At the initial hiring stage, gender stereotypes could lead to women's lower chances of being called back after submitting applications and getting an offer after job interviews; Upon being hired, women are likely to receive lower starting wage, work in highly sex segregated positions (Bielby and Baron 1986; Padavic and Reskin 2002), and have less chance and wait longer time in promotion and wage raise at later stage. The stereotyping process is quite tenacious because of its cognitive 
efficiency (Fiske 1998; Reskin 2002). It operates largely unconscious in most circumstances, which better explains the prevalence and persistence of discriminatory practices at workplaces (Reskin 2000).

According to social cognitive theory, employers' evaluations, perceptions, and stereotypes of female workers are more likely to be activated by their discernable characteristics, such as marital status, pregnancy status, and the number and age of their children. The motherhood penalty literature has well documented the negative impact of having children on a woman's job application, wages, and career promotion (Budig and England 2001; Budig and Hodges 2010; Correll et al. 2007; Petersen et al. 2014). However, employers' stereotypes and discrimination against women may also be well activated and strengthened by social policy and relevant factors in the broader social milieu. For instance, cross-country evidence has shown that extension of paid maternity leave has paradoxical negative impact on employment, wages, and career training for young female workers, including women who take maternity leave as well as those who do not (Balfe 2014; Lai and Masters 2005; Puhani and Sonderhof 2008). In particular, Balfe (2014) examines how a policy reform in the United Kingdom to increase paid maternity leave from 26 weeks to a maximum of 39 weeks in 2007 affects relative female-male labor market outcomes. Results from her quasi-experimental design reveal that such an increase in maternity leave generosity leads to a deterioration in female relative wages and in increase in relative female redundancies. These universal negative impacts of paid maternity leave on labor market outcomes of young women suggest that employer may discriminate women not only according to their realized behaviors of taking maternity leave, but also based on their unrealized likelihood of taking similar action. In terms of the latter, aggregate fertility may serve as a convenient and important source of information for employers to assess female workers' likelihood of taking maternity leave and contribution to the firm, which may lead to discrimination at the workplace. Prior findings by Yip and Wong (2014) about negative effect of aggregate fertility on young women's wage has lend credible empirical support for this possible mechanism.

Gender stereotyping and discrimination do not exist in a structural vacuum, but they are rather to be embedded in specific organizational and institutional context (Baron 1984; Granovetter 1985). Recent research on motherhood penalty has demonstrated that the wage reduction associated with number of children is smaller in occupational settings with greater autonomy, lower teamwork requirements, and less competitive pressure, lending modest support to the 
changing employer discrimination across workplace (Yu and Kuo 2017). Other studies examining discrimination toward women have also reported that the unexplained gender pay gaps are considerably larger in the private than in the public sector (Hoffnar and Greene 1996; Mandel and Semyonov 2014). ${ }^{6}$ These findings point to the importance of structural characteristics such as work conditions and employment sector in either amplifying or mitigating gender discrimination and inequality in the labor market. In this vein, one would logically surmise that gender discrimination associated with aggregate fertility is likely to vary under different structural conditions: it may be less visible at workplace with better implemented equal opportunities and antidiscrimination policy such as the public sector, while more salient in settings emphasizing efficiency and profit-maximizing such as the private sector.

Guided by these theoretical perspectives, this study examines the direct (negative) influences of aggregate fertility on young workers' earnings as well as variation across different economic sectors in post-socialist urban China. In the next section, we introduce the relevant Chinese context and propose our research hypotheses.

\section{The Chinese context}

\subsection{Marketization and widened gender earnings gap}

Post-socialist urban China offers a particularly interesting case to explore the mechanism of statistical discrimination in gender employment inequality. The Chinese constitution formally guarantees women equal rights with men in all spheres of life and assures them of equal pay for equal work (Ji et al. 2017; Maurer-Fazio and Hughes 2002). During the pre-reform period and under state collectivism, women fared relatively well under the government's promotion of social egalitarianism and gender equality. Women were compelled to participate in the workforce under the slogan of "women holding up half the sky" and paid almost equally to male workers regardless of efforts and performance. For example, Kidd and Meng (2001) reported that the male-female difference in monthly wage was only $14 \%$ during the early 1980 s, a relatively small gap compared to other advanced industrial societies during the same period.

The introduction of market reform in the 1980s saw the emergence of a vibrant private

6 Still other studies, however, find little variation in discrimination across sector (Byron 2010; Leasher and Miller 2012). 
sector. When recruiting and rewarding employees, profit-driven private firms are likely to prioritize economic efficiency over social equality, even as government agencies and state enterprises hang onto the latter. This potentially gave rise to discrimination. Although Chinese official statistics rarely make detailed comparisons of men's and women's wages (Maurer-Fazio et al. 1999; Rawski 2003), statistics compiled from survey data generally suggest that the gender earnings gap in urban China has widened considerably over the past two decades along with rapid marketization (He and Wu 2017, 2018; Li C. and Li S. 2008; Maurer-Fazio et al. 1999; Wang and Cai 2008; Zhang 2004; Zhang J. et al. 2008). ${ }^{7}$ Figure 1 shows the unadjusted female-male earnings ratio for employees in urban labor markets and the degree of marketization (measured by employment shares of the private sector) in urban China from 1988 to 2011. During the period, the degree of marketization skyrocketed, with the private sector employment shares growing from almost $0 \%$ in 1988 to $52.7 \%$ in 2011 . At the same time, gender earnings equality declined, with the gender wage ratio dropping from $86.3 \%$ in 1988 to $77.4 \%$ in $2011 .{ }^{8}$ While women in the government/public institution continue to fare relatively well, their counterparts in the private sector have lost out with lower wages ( $\mathrm{He}$ and $\mathrm{Wu} 2017$ ).

[Figure 1 Here]

\subsection{Discrimination and variation across economic sector}

Does the widened gender earnings gap in urban China signify increased discrimination against women, particularly in the more marketized private sector? Empirical evidence so far remains mixed due to the difficulty of measuring and quantifying elusive forms of discrimination. Through decomposing the gender wage gaps of employees in private and public sectors in Shanghai and Jinan, Liu et al. (2000) found that the ratio of unexplained gender wage gap to the total wage gap was smaller in private firms than those in the state sector. ${ }^{9}$ They concluded that the relative share

7 Shu and Bian (2003) differ. Based on datasets from China Household Income Project in 1988 and 1995 and city-level data for 1995, the authors detected neither longitudinal change nor city-level variation in the gender gap in earnings.

${ }^{8}$ A similar decreasing trend of gender earnings equality has been reported by the Global Gender Gap Report (World Economic Forum 2006-2014), in which estimates of the female-tomale ratio of earned income (PPP US\$) are even lower than $70 \%$.

${ }^{9}$ However, the authors acknowledged that the absolute size of the unexplained gender wage 
of discrimination in the gender wage differential declined substantially across ownership types from the state to the private sector. In contrast, other studies reported that the majority of gender earnings differentials could be attributable to sex discrimination, especially during recent years ( $\mathrm{Li}$ C. and Li S. 2008; Maurer-Fazio and Hughes 2002; Wang and Cai 2008; Wang et al. 2008; Zhang 2004; Zhao et al. 2019). For instance, using a more detailed measure of market liberalization (enterprise-ownership type, enterprise age, and workers' methods of finding employment), Maurer-Fazio and Hughes (2002) found that both the absolute size of the wage gap and the proportion of unexplained gap (after accounting for various observed characteristics) were largest in the most liberalized joint-venture sector, but smallest in the least liberalized state sector.

In view of such discrepancy, it is arguably more illuminating to investigate the mechanisms of discrimination in a more direct way than simply attributing unexplained wage gaps to discrimination. To this end, our first research goal is to proxy period ASFR as the unrealized likelihood of women taking maternity leave that could be utilized by employers to discriminate against women, and explore whether $A S F R$ would be differentially related to young men's and women's earnings in urban China. Moreover, previous studies on China have well established that economic sector remains a salient structural factor that profoundly shapes individuals' life chances including both economic and subjective well-being (He and Wu 2017; Wang and Xie 2015; Wu 2002, 2013; Wu and Song 2014; Xie and Wu 2008; Zhang and Wu 2017). Regarding the enlarged gender pay gap across sectors, one possible culprit might be that employers in the private sector impose more penalty associated with aggregate fertility on women's earnings. Our second research goal is therefore to examine whether and how the statistical discrimination based on period ASFR would vary by sector, thus offering additional insight in understanding the sectoral differences in gender earnings inequality in urban China.

\subsection{China's maternity leave policy and research expectations}

Since its founding in 1949, the socialist Chinese government has passed a series of laws, regulations, and policies to protect the rights of female workers at the workplace. In June 1988, the Chinese government issued "Regulation Concerning the Labor Protection of Female Staff and Workers," stipulating that female workers' basic salaries cannot be reduced and their labor

gap was larger in the private sector than in the state sector. 
contracts cannot be cancelled during pregnancy, maternity leave, and the nursing period. The law is applicable to female workers in all state agencies, mass organizations, enterprises, and other work units. In April 2012, the Chinese government issued another regulation, "The Special Rules On the Labor Protection of Female Employees," to increase maternity leave from 90 days to 98 days and implement detailed regulations on maternity leave in situations of dystocia, multiple births, and miscarriage. There has not been any legal regulation supporting paternity leave until recently. ${ }^{10}$ With such promises, some scholars argue that employers, especially those in the private sector, would have a stronger motivation to act on their perceptions that childbirth and family responsibilities render female workers less productive, less committed to work, and that maternity leave and its associated benefits make women too costly to employ (Zhang Y. et al. 2008).

Translated into the terms of our study, this means that period aggregate fertility rates, representing the likelihood of women to take maternity leave, will probably play an important role when employers reward female workers, but not male workers. Despite the enforcement of the one-child policy from the 1970s to its formal end in 2016, resulting in a drastic drop in fertility in urban areas, we believe that two demographic processes would reinforce the significance of period $A S F R$ on women's earnings, namely, almost universal marriage for women and most births tend to occur within the first few years of marriage (Raymo et al. 2015). We therefore expect an overall negative association between period $A S F R$ and earnings among young women of prime fertility age, but not among young men, in post-reform urban China.

Furthermore, we postulate differential links between period ASFR and women's earnings across economic sectors. As young women at prime fertility age are likely to get married, become pregnant, take maternity leave, give births, and bear family responsibilities, profit-driven private sector employers are likely to evaluate the productivity of female employees to be lower, and thus offer lower wages to them relative to male employees with comparable characteristics. By contrast, the socialist ideology for gender equality, stronger state protection, and different budget and cost constraints would render this gender-oriented statistical discrimination based on aggregate fertility less effective in the state sector. We therefore expect the negative association between period $A S F R$

${ }^{10}$ Local governments may set regional policies regarding paternity leave and its length, but they tend to vary widely across regions. Moreover, very few, especially private, enterprises are likely to adopt these policies. 
and women's earnings to be much stronger in the private sector, but relatively weak or even negligible in the state sector.

\section{Method}

\subsection{Data and sample}

Our data is an extracted random sample $(\mathrm{N}=344,826)$ from the one-percent intercensal population sample survey of China in 2005 (also known as "mini-census"), conducted by the National Bureau of Statistics of China. The mini-census adopts a multi-stage stratified clustering probability sampling technique and collects social and demographic information on the national population, covering approximately 17 million people in all 31 provinces, municipalities, and autonomous regions. It includes rich and detailed information on respondents' monthly income, work unit sector, working hours, labor contract and fringe benefits, in addition to employment status, occupation (2digit code), hukou status, place of hukou registration, current place of residence, education, and other demographic characteristics (Wu 2014).

We restrict the sample in the following ways. Since we study the labor market in urban China, respondents living in cities and towns at the survey point were kept in the sample $(\mathrm{N}=$ $163,616)$. We then restrict the sample to those who worked non-zero hours last week $(\mathrm{N}=107,485)$ and were not enrolled in school (dropping 17, 565 respondents). Because our focus is earnings of employees, we exclude people who reported to be employers, self-employed, and family workers, and focus on employees working at enterprises $(\mathrm{N}=49,064)$. According to Proposition 2 in Yip and Wong's model (2014) that the gender wage gap will rise with age until prime fertility age, we follow their practice to model earnings among workers up to their prime fertility age. This will also avoid contaminations from other discriminatory factors or processes that affect earnings after prime fertility age. Based on compilations from the 2005 mini-census, the prime age with the highest fertility rate was $26 .{ }^{11}$ Given that urban women rarely give births under age 20, we thus restrict the sample to employees aged between 20 and 26 years old $(\mathrm{N}=8,901)$. After excluding cases with missing data on earnings and other covariates, the final size of our analytical sample is

11 In the data, $77 \%$ of women were from urban cities where the prime fertility age was 26 , while the prime fertility age was 25 in small towns. Our results remain the same even if we use 25 as the prime fertility age (see robustness check later). 
8,619 with 4,449 women and 4,170 men.

\subsection{Measures}

The dependent variable is logged monthly earnings, by taking the logarithmic values of respondents' self-reported income in the last month (October 2005). Because we focus on employees, their monthly income should closely match their actual earnings including wages, salary, and bonuses from jobs (He and $\mathrm{Wu} 2017)$.

Our key independent variable is ${ }_{1} F_{x}$, the period age-specific fertility rate $(A S F R)$ by single age, a measure directly compiled from the 2005 mini-census data. Its numerator is the number of new births $\left({ }_{1} B_{x}\right)$ born to women living in cities and towns between ages $x$ and $x+1$ during November 1, 2004 to October 31, 2005, and its denominator is the period person-years lived (PPYL) by women living in cities and towns between ages $x$ and $x+1$ in the same period. The PPYL is usually estimated using the mid-period population times the period length. In our study, the period is pretty short with only one-year length, and we assume the number of women at a particular age on October 31, 2005 is the same as the corresponding number at the middle of this one-year period. The period $A S F R$ could therefore be calculated using the following equation:

$$
{ }_{1} F_{x}={ }_{1} B_{x} / P P Y L,
$$

Note that the period $A S F R$ represents the age-specific fertility rates of a "synthetic cohort" rather than a real cohort, based on the fertility information of women at different ages in the study period (Wachter 2014). Although the period ASFR assumes today's fertility rates continue unchanged into the future, we believe it is a more pertinent measure than real cohort fertility rates because complete cohort fertility data are often one or two generations ago and thus not very relevant to describe today's childbearing in rapidly changing China; period fertility information is readily accessible from mass media and official publications and comprehensible for laymen in taking social action. Using 2005 mini-census data, we obtain a continuous measure of period $A S F R$ in Chinese cities and towns ranging from $21.43 \%$ to $100.53 \%$ for women aged 20 to 26 . This measure may induce some potential endogeneity problem to the extent that childbirths of women in our sample may be influenced by their income, benefits, and/or other job characteristics. For

robustness check, we also construct alternative measures of period $A S F R$ in Chinese cities and towns during 2002 to 2005 using external sources of fertility data at the national-level from the China Population Statistics Yearbook (National Bureau of Statistics 2003, 2004, 2005, 2006). These period $A S F R$ measures are based on all live births regardless of parity. For comparison 
purpose, Figure 2 depicts all period $A S F R$ measures calculated for women during 15 to 40 years old, ${ }^{12}$ with the $y$-axis representing new births per 1,000 women and the $x$-axis indicating age. Although the period $A S F R$ measure calculated from the 2005 mini-census data is slightly lower than that on national-level based on the official statistics in the same year, these two measures are highly correlated $(r=0.97)$. Regardless of data sources, the total fertility rate in 2005 is lower than those in previous years, indicating China's continuing transition into a low fertility regime.

[Figure 2 Here]

Consistent with prior studies ( $\mathrm{He}$ and $\mathrm{Wu} 2017$ ), economic sector is a three-category variable distinguished by work unit ownership: government agency/public institution, state-owned and collective enterprises, and the private sector (individual or private enterprises and others). We expect state protection for women to decrease as the distance from the administrative/redistributive center increases from government agency/public institution to the private sector.

We also control for other individual characteristics that are important in determining workers' wage: years of schooling, potential work experience, occupation, sex segregation by occupation, work hours last week, work contract, marital status, number of children, hukou status, and ethnicity. Respondents' level of education is converted into years of schooling: illiterate $=0$; primary school $=6$; junior high school $=9$; senior high school $=12$; specialized college $=15$; university $=16$; and graduate school $=19$. Potential work experience is calculated by subtracting years of schooling and six years from actual age. In so doing, workers' age, years of schooling, and potential work experience are dependent on each other, and work experience is automatically omitted when including all three variables in the same model. We therefore only include years of schooling and potential work experience (and its squared term) that could better represent workers' human capital in the analyses. ${ }^{13}$

Occupation is coded into five broad categories: $0=$ managerial; $1=$ professional; $2=$ clerical; $3=$ sales/service; and $4=$ manual. We use a simple measure of sex composition by occupation, the percent of female workers in the total number of workers within the same

12 This captures fertility rates among the majority of reproductive age groups. Figures presenting the period ASFR between age 15-49 are available upon request.

${ }^{13}$ Regressions using age instead of work experience yield the same findings. 
occupation (\% Female) calculated from the urban sample in the 2005 mini-census. ${ }^{14}$ Work hours last week is respondents' self-reported total work hours during the past week before being interviewed. Work contract, marital status, hukou status, and ethnicity are all dummy variables (1 for married, no work contract, rural hukou and non-han, and 0 otherwise). Number of children is a continuous measure also calculated from the 2005 mini-census. Specifically, for female workers, we use their self-reported number of children ever born to them; For married male workers, we first match their spouses' information based on household relationships in the household roster, and then obtain the corresponding number of children. ${ }^{15}$ A value of 0 is assigned for unmarried male workers. Finally, industry and province dummies are included to account for potential industrial and regional heterogeneities in workers' earnings. ${ }^{16}$

14 There are 73 occupations (2-digit code) in total in the 2005 mini-census. We are unable to replicate significant interaction between occupational sex segregation and ASFR found in the original analyses by Yip and Wong (2014). This may be due to a relatively low level of sex segregation among young Chinese workers relative to their counterparts in Hong Kong. Since our central concern is whether the effect of $A S F R$ may vary across economic sectors, we decide not to pursue further in our current investigation.

15 Question R2 asks individuals about their relationships with the household head, with answers ranging from 0-9: $0=$ head; $1=$ spouse; $2=$ children; $3=$ parents; $4=$ In-laws parents; 5 = grandparent; $6=$ son/daughter-in-law; 7 = grandchild; $8=$ siblings; and $9=$ other. For a married man who reports "household head" or "spouse", we compute the number of children based on information of his spouse if he is married. For a married man who reports "children" or "son/daughter-in-law" in a household, we match this person with his spouse who answers " 6 " with exact year and month of marriage, and then obtain their corresponding number of children. For a married man with other responses, if we are able to locate another woman within the household with identical year and month of marriage, then the number of children could be ascertained from their spouses' records. If the male respondent has more than one marriage or we are unable to locate his spouse's information, we treat the number of children as missing. After matching, the number of children of male workers in our sample ranges from 0 to 3, with only $5.65 \%$ of cases have missing values.

16 The 2005 mini-census records 92 detailed industries (2-digit code), and we collapse them 


\subsection{Analytical strategy}

We use ordinary least square (OLS) regression to model logged monthly earnings of women and men as a function of period $A S F R$, economic sector, and other covariates. Specifically speaking, we estimate two models separately for women and men: Model 1 is the baseline model that investigates the main effect of period ASFR net of economic sector and all other covariates; Model 2 adds interactions between period $A S F R$ and economic sector to investigate the sectoral variation in the association between period $A S F R$ and monthly earnings. Earlier version of results based on robust regression yield similar findings (available upon request). However, as robust regression is more appropriate to use when there are outliers that may distort OLS estimates (Treiman 2009; Verardi and Croux 2009), which is not the case in our data, we choose to present OLS regression results.

\section{Results}

\subsection{Descriptive results}

Descriptive statistics are presented in Table 1, where variables that differ significantly by gender are indicated using bold font. The monthly earning of women was 928 yuan in October, 2005, 89\% of the earnings of their male counterparts. The average value of period $A S F R$ is $76.59 \%$. Compared to male employees, female employees had higher representation in the civil service sector, lower in state-owned and collective enterprises, and equal representation in the private sector. There was not much gender difference in years of schooling, but women had less work experience than men. Women had a higher representation in professional and sales/service positions, whereas men were over-represented in manual positions. The average percent of female employees by occupation was $51 \%$ among women, but only $37 \%$ among men. Women also worked less hours last week and were less likely to be working in nonstandard jobs without work contracts than men. A higher

into 15 broader industries: 0 = agriculture; $1=$ mining; 2 = manufacture; $3=$ electricity, steam, water production and supply; $4=$ construction; 5 = geological exploration and water management; $6=$ transportation; $7=$ sales, retail, and commercial brokerage; $8=$ lodging and catering; $9=$ finance; $10=$ real estate; $11=$ service; $12=$ public health and sports; $13=$ culture and education; 14 = state, social, and other organizations. 
proportion of women were married and had more children. A larger percentage of men had rural hukou, probably reflecting a larger proportion of rural-to-urban migrants among young men. On the other hand, there was not much difference in ethnicity between men and women.

[Table 1 Here]

Figure 3 displays the average monthly earnings by gender and the female-to-male earnings ratio between age 20 and 35 . Not only did male workers consistently earn more than their female counterparts across the entire range, but the gender earnings gap tended to increase after a relatively small gap at the early career stage (at or before age 24). While the earnings gap was much larger after age 26 , our current focus is to explore whether statistical discrimination associated with period $A S F R$ could differentially impact men's and women's earnings in the years up to prime fertility age. To account for the substantial gender gap beyond the prime fertility age, other important social and economic factors should be explored together with statistical discrimination (Yip and Wong 2014).

[Figure 3 Here]

\subsection{Multivariate results}

Table 2 presents estimates from OLS regression models, with Models 1a and 2a pertaining to female workers and Models $1 \mathrm{~b}$ and $2 \mathrm{~b}$ to male workers. To save space, we only discuss results of our key research interest and omit those of covariates. First, as shown in Model 1a, the coefficient of ASFR was strongly negative among female workers $(\beta=-0.002, p<0.05)$. Net of other covariates, an increase of 10 births per 1,000 women would result in around $2 \%$ decrease in women's monthly earnings $(10 * 0.002=0.02)$. In our analytical sample, the average value of period $A S F R$ is $76.59 \%$, which is associated with about $15 \%$ decrease in women's monthly earnings ( $76.59 * 0.002=0.15)$. This negative influence of $A S F R$ was substantial and could offset the positive influence of human capital on monthly earnings. For example, one year increase in schooling was associated with about 0.10 increase in young women's logged monthly earnings and this benefit could be mitigated or offset completely by the negative coefficient of $A S F R$.

[Table 2 Here]

Model 2a reveals a sharp contrast in the interaction between $A S F R$ and economic sector. The main coefficient of $A S F R$ is nearly zero and insignificant, indicating that female workers' monthly earnings in state-owned and collective enterprises (the reference category) were not much affected by aggregate fertility. The interaction term between $A S F R$ and government agency/public 
institution is significantly positive $(\beta=0.002, p<0.05)$, whereas that between ASFR and the private sector is significantly negative $(\beta=-0.002, p<0.05)$. The significantly negative influence of $A S F R$ detected in Model 1a primarily reflects that among the private sector, where a 10-unit increase in $A S F R$ would lead to around $2 \%$ decrease in women's monthly earnings. In the government agency/public institutions, however, a 10-unit increase in $A S F R$ would be associated with $2 \%$ increase in women's monthly earnings.

The above results are consistent with our expectation that young female workers in the private sector experienced earnings penalty associated with aggregate fertility, probably reflecting statistical discrimination from their employers (either consciously or unconsciously). The finding that young female workers in the state sector not only did not suffer from such penalty, but actually enjoyed an earnings premium is somewhat surprising. This might be due to the fact that workers in government agencies or public institutions rarely get fired and have access to generous fringe benefits, enjoying an "iron rice bowl" (Wang and Xie 2015). Work interruptions due to pregnancy and childbirths are thus not frowned on and have little impact on their accumulated working experiences. At the same time, however, the positive association between ASFR and women's earnings might actually reflect rewards to strong motivations and work commitment shown by women early in their government career, factors that cannot be fully captured in our analyses.

Does aggregate fertility influence earnings of young male workers? As expected, results in Model $1 \mathrm{~b}$ reveal little relationship between period $A S F R$ and monthly earnings on average among young men, indicating that men's earnings were generally not linked to the aggregate fertility. There is some evidence that relative to young men working in SOEs or collective enterprises, those in government agencies/public institutions received significantly lower earnings. In model $2 b$, the main coefficient of $A S F R$ and its interactions with economic sectors are all insignificant, indicating little variation in the effect of $A S F R$ across economic sectors. In fact, the association between period $A S F R$ and men's monthly earnings is significant in none of the three sectors. Taken together, these results are consistent with our earlier expectation that aggregate fertility was significantly related to lower earnings among women, but had little influence on men's earnings.

\subsection{Sensitivity check}

Robustness to ASFR at the national level Since the $A S F R$ we construct from the mini-census may not correspond exactly to national figures and employers may refer to previous years' aggregate 
fertility when making decisions, we re-estimate our models using national-level period ASFR collected from official statistics from 2002 to 2005. Table A1 reveals consistent patterns with earlier conclusions: (1) aggregate fertility was not related to men's monthly earnings but had moderately negative influences on women's earnings; and (2) female workers in private firms faced increasing penalties all the way to the prime fertility age. Interestingly, influences of period $A S F R$ on women's monthly earnings tend to be the strongest in 2005, suggesting that employers probably utilize recent fertility information to assess productivity and set wages.

Robustness to different age ranges In reality, employers may know little about the exact prime fertility age, but rather have a vague idea about the range of prime fertility age. We thus vary workers' age by 1 to 2 years from the real prime fertility age at both directions $(24,25,27$, and 28 years old), and conduct the same set of analyses as those in Table 2 among employees aged 20-24, 20-25, 20-27, and 20-28 years old. Table A2 show substantively similar results in terms of the gender-asymmetric associations between period $A S F R$ and monthly earnings among young women and men.

Robustness to occupation fixed effects The negative influences from ASFR on women's earnings might reflect penalties for women from other sources such as compensating differentials and flexibility within occupations (Goldin 2014). To reduce potential confounding factors, we reestimate previous models with occupation fixed effects by including 72 occupational dummies (we drop the variable $\%$ Female while controlling for occupation fixed effects). Consistent with prior findings, results in Table A3 still show an average negative influence from ASFR on women's earnings, primarily reflecting the negative influence of period $A S F R$ in the private sector. For men, $A S F R$ on average was not related to their earnings.

Robustness to migration selection We also check whether and to what extent our main results would be affected by rural-to-urban migrants. OLS results from the same models in Table 2 after excluding inter-province rural-to-urban migrants and all rural-to-urban migrants (both inter- and intra-province) show that, among young women, the patterns of the $A S F R$ effect and its variation across sectors are basically the same as those in the main analyses; on the other hand, period ASFR still did not matter for young men's earnings (results available upon request).

\subsection{Supplemental analyses}

Perceptions associated with fertility of employers, particularly those in the private sector, may 
differ by characteristics of workers and jobs. We therefore explore the influence of period $A S F R$ and its sectoral variation by re-estimating Model $1 \mathrm{~b}$ in Table 2 among subgroups of women stratified by their work experience, motherhood status, and occupation. First, conceptually speaking, $A S F R$ could affect the initial wage of new workers who just started a job in a specific year, and/or affect the earnings of senior workers already in the job in a specific year. Our previous estimations are a combined "average" reflecting these two processes. As shown in Columns 1-3 of Table 3, negative effects of period $A S F R$ on average and those in the private sector are largest for women with least work experience (3 years and less) and tend to decrease as their work experiences increase. Among young women work less than 4 years, an increase in 10 births per 1,000 women is associated with $6 \%$ decrease in their monthly earnings in the private sector, while the corresponding impacts from $A S F R$ are about 5\% for women with experiences of 4-5 years, and only $2 \%$ for women with experiences of 6 years and more. These patterns indicate that the discriminating process associated with aggregate fertility is operating for all women, but women who recently start their jobs are particularly vulnerable to such negative influences from aggregate fertility.

Second, we examine whether the discrimination associated with aggregate fertility would differ by motherhood status between childless women and mothers. As shown in Columns 4-5 of Table 3, previous findings about negative influence of $A S F R$ and its sectoral variation are primarily driven by those among childless women, while not observed among mothers. To the extent that childless women are more likely to give births at their current jobs than mothers (under China's one-child policy), such heterogeneity is consistent with our theoretical argument that the unrealized, rather than realized likelihood, of taking maternity leave matters for the statistical discrimination associated with period $A S F R$.

Third, as employers' perceptions based on aggregate fertility may vary across occupations, we also re-estimate models in three broad occupational groups: managerial and professional; clerical, sales, and services; and manual occupations. As shown in Columns 6-8 of Table 3, young women working in clerical, sales and services occupations are negatively affected by $A S F R$, whereas the negative influences of $A S F R$ are invisible in the other two occupations. The insignificant coefficients of $A S F R$ on women in managerial and professional positions are not consistent with the model prediction by Yip and Wong (2014) that the more productive the female worker is, the greater will be the impact of fertility rate on wage. We suspect that young women in 
managerial and professional occupations in general may enjoy more flexible and generous work conditions and benefits to partly mitigate the negative impact associated with aggregate fertility. Future research may be needed in order to understand better whether this particular finding is applicable in all or only some specific societies.

[Table 3 here]

Finally, all of our prior findings only consider aggregate fertility on the national level, while employers' perceptions might be shaped by fertility information at the local level. We collect official statistics of period $A S F R$ from statistical yearbooks released by 23 provinces in 2005 (fertility data are unavailable in eight provinces: Tianjin, Shanxi, Inner Mongolia, Jilin, Hubei, Hunan, Yunnan, and Tibet). The mean value of period ASFR among these 23 provinces in 2005 is $69.49 \%$, lower than that in our analytical sample. Supplementary analyses in this reduced sample reveal that among all women aged 20-26, the influence of province-level ASFR is negative but insignificant, and no significant sectoral variation exists in such influence; among childless women, the negative effect of province-level ASFR is marginally significant ( $p=0.07)$ in the private sector, and its magnitude reduces to half compared to that using national-level ASFR; province-level ASFR is still not related to men's earnings. The reduced sample size and potential underreporting in province-level fertility may lead to weaker evidence using provincelevel period $A S F R$. It is, however, still plausible that employers may also utilize fertility information at the local level (at either the province- or prefecture-level) to assess female workers' productivity.

\section{Discussion}

In this study, we explored one specific statistical discrimination mechanism based on aggregate fertility, a practice might be adopted by employers to discriminate against young women in offering them earnings. Relying on data from post-reform urban China, our analyses show genderasymmetric associations between period $A S F R$ and monthly earnings among Chinese young women and men at and before the prime fertility age. Period $A S F R$ was, on average, negatively related to earnings among women, but not among men. This negative influence of $A S F R$ was largely restricted to women working in the private sector, while diminished in the SOEs and collective enterprises, and even became positive among those in government agency/public institutions. By contrast, young men's earnings were generally not negatively influenced by 
aggregate fertility.

An overall negative influence of period $A S F R$ on women's earnings suggest that Chinese employers are likely to use aggregate fertility information to discriminate against female workers beyond individual characteristics like marital status and the number of children. Indeed, China's widening gender pay gap since the early 1990s is, at least partly, attributable to increasing discriminatory practices against women after the loosening of state control and the penetration of market forces into the economy. Anecdotal evidence of workplace discrimination in China reveals that employers, especially those in private enterprises, often consider female workers during pregnancy, maternal leave, and the lactation period to be less productive, disrupting the normal operation and increasing the operating cost of their firms (Human Rights Watch 2018). Because of such perception and stereotyping of women, many employers adopt unfair clauses and regulations to restrict application from women during the recruitment and hiring process (Kuhn and Shen 2013), and even arbitrarily deprive their employment rights and promotion opportunities when they get pregnant or need to take care of children and family (Li and Zhang 2010). Our empirical results corroborate prior studies of increasing statistical discrimination against women under market reforms.

Juxtaposed to the discrepant previous findings on whether and how discrimination against women increased with increasing privatization and marketization in post-reform China, our study illustrates different patterns of discriminatory practices across economic sectors, where the genderoriented statistical discrimination based on $A S F R$ was more prominent in the increasingly marketized private sector, but paradoxically negative in the state sector. The negative influence from $A S F R$ on women's earnings reflect the widespread discrimination toward women in the private firms, regardless of their sizes (Human Rights Watch 2018). On the other hand, the socialist legacy of generous benefits and relatively stable and continuous career trajectories for state employees may account for women's earnings premium in the state sector. However, we remain cautious as the positive association may be transitional and the so-called premium may disappear in the future, when there is a streamlining in public expenditure and cutback in government payroll. Future research investigating the exact relationship between fertility (aggregate and individual) and women's earnings in the state sector over time may further illuminate such development.

Among young men, however, we did not find evidence of a negative relationship between $A S F R$ and their earnings, indicating that men are usually not subject to discrimination related to 
aggregate fertility information. To a large extent, this gendered influence of $A S F R$ on earnings of young women and men reflect the fact that Chinese employers usually hold distinctive preferences when hiring and rewarding men and women. Recent studies have demonstrated that in China, employers explicitly state their gender preferences when posting job advertisements (Human Rights Watch 2018; Kuhn and Shen 2013; Woodhams et al. 2009). Some employers may even blatantly ask female applicants about their personal situation, such as marital status, fertility intention, and number of children. ${ }^{17}$ Such entrenched gender stereotypes held by employers help maintain and perpetuate highly segregated expectations of men and women's roles at work, hindering women's progress in the labor market (Woodhams et al. 2009). In addition, our multivariate analyses reveal that a group-based discrimination toward women associated with aggregate fertility may also be operating and exert independent influence on women's earnings beyond discrimination based on women's individual characteristics. Unlike explicit discrimination expressed by employers, such statistical discrimination may work in an implicit way, when employers' perceptions and evaluations of the average productivity of women are linked to the macro-level fertility information, a pattern consistent with predictions of social cognitive theory (Reskin 2000, 2002). Taken together, it is not uncommon for many women to feel upset and frustrated when they look for jobs and work in an increasingly women-unfriendly labor market.

We acknowledge several limitations in our study that point to possible directions for future research. First, the gender earnings inequality examined pertains only to workers' beginning career. While statistical discrimination is important at this early stage, other social processes are probably more significant at a later stage past the prime fertility age. A further study of effects of fertility behaviors and occupational sex segregation on the earnings of women beyond the prime fertility age in urban China would be illuminating, as occupational sex segregation has been documented to be an important factor contributing to the gender pay gap in China (He and $\mathrm{Wu} 2017$; Shu 2005; Wu. Y and Wu. X 2008, 2009). Second, potential underreporting in new births in China may lead to measurement error in aggregate fertility that attenuates our estimations using either the nationalor province-level period $A S F R$. Results in this study may thus represent the conservative side of

17 "Stop Asking Women About Childbearing Status, China Tells Employers." The New York Times, February $21^{\text {st }}$, 2019. https://www.nytimes.com/2019/02/21/world/china-genderdiscrimination-workplace.html 
the true effect of $A S F R$. That being said, aggregate fertility being the first and only indicator of statistical discrimination examined so far, much remains to be done. To be properly identified, any measure of statistical discrimination must pertain to women's aggregate characteristics that are readily quantifiable.

Third, we have no data to examine employers' actual evaluations (and cognitive biases) of female workers. Employers' perception may not only come from direct interactions with employees, but could be influenced by the mass media. Chinese mainstream media are increasingly suggesting women's return to traditional roles in the domestic sphere and emphasizing women's private rather than public life during the market transition (Sun and Chen 2015). To the extent that this media rhetoric may influence employers' perceptions and help reinforce gender stereotypes of women as inferior workers, the negative effect of period ASFR on young women's earnings in the private sector may be conflated by the mass media effect. To better elicit employers' preferences/expectations of workers' productivities, qualitative studies probing the minds of employers about their evaluation, hiring, promotion, and layoff decisions would greatly enrich and supplement our understanding of gender discrimination in the labor market. Future research may also rely on novel methods such as survey experiment as utilized by recent studies (Mari and Luijkx 2020).

Lastly, the cross-sectional design of our study only produces associations between aggregate fertility and workers' earnings. Although the main findings are robust to alternative measures of period $A S F R$ in previous years, our results should not be interpreted as causal. Besides, cross-sectional data and analyses within workers during prime fertility age also prevent us from clearly distinguishing between age, cohort, and period effects. More appropriate datasets with rich information, such as longitudinal and firm-level data, may allow a more thorough investigation about how women and men are differentially treated in terms of earnings and other labor market outcomes.

Despite these limitations, our study has important contribution and policy implication. We have extended the gender-oriented statistical discrimination model proposed by Yip and Wong (2014) from Hong Kong's labor market to China's transitional economy, showing its generalizability to wider contexts. The variation in associations between ASFR and women's earnings across economic sectors in China highlights the importance of considering how structural factors may moderate such gender-oriented statistical discrimination. These structural factors may 
be context-specific, which include not only economic sector, but also other factors at the firm and organizational level. Together with those from Yip and Wong (2014), our study complements prior research about discrimination based on individual characteristics, and highlights another implicit, but important discriminatory practice that is related to macro-level fertility information. The existence and magnitude of such discrimination are likely to depend on the generosity of maternity leave policy and public support for childcare in a certain society. In societies with generous maternity leave and social support for childrearing such as Nordic welfare countries, firms may be less incentivized to discriminate against women based on aggregate fertility. In contrast, in liberal countries with minimal or limited public childcare support like the United States and the United Kingdom, young women are likely to be discriminated more seriously by employers based on fertility rate (the magnitude may vary by paid and unpaid leave). More comparative research is needed to examine the variation in the effect of $A S F R$ by welfare regime and childcare policy. 


\section{References}

Aigner, D. J., \& Cain, G. G. (1977). Statistical theories of discrimination in labor markets. Industrial and Labor Relations Review, 30(2), 175-187.

Arrow, K. J. (1971). The theory of discrimination. In O. Ashenfelter, \& A., Rees (Eds.), Discrimination in labor markets (pp. 3-33). Princeton, New Jersey: Princeton University Press.

Arrow, K. J. (1972). Models of job discrimination. In A. H. Pascal (Eds.), Lexington, Racial discrimination in economic life (pp. 83-102). MA: D.C. Health.

Balfe, C. (2014). Maternity leave duration and female-male relative labour market outcomes. https://pdfs.semanticscholar.org/0a6c/d8561eb13735da26af8c4389103b574aa7f3.pdf.

Baron, J. N. (1984). Organizational perspectives on stratification. Annual Review of Sociology, 10: 37-69.

Becker, G. S. (1957). The economics of discrimination. Reprint, Chicago: University of Chicago Press, 1971.

Becker, G. S. (1985). Human capital, effort, and the sexual division of labor. Journal of Labor Economics, 3(1), S33-S58.

Bertrand, M., \& Mullainathan, S. (2004). Are Emily and Greg more employable than Lakisha and Jamal? A field experiment on labor market discrimination. American Economic Review, 94(4), 991-1013.

Bielby, W. T. (1991). The structure and process of sex segregation. In R. R. Cornwall, \& P. V. Wunnava (Eds.), New approaches to economic and social analysis of discrimination (pp. 97112). New York, NY: Praeger Publishers.

Bielby, W. T., \& Baron, J. N. (1986). Men and women at work: Sex segregation and statistical discrimination. American Journal of Sociology, 91(4), 759-799.

Blau, F. D., \& Kahn, L. M. (2017). The gender wage gap: Extent, trends, and explanations. Journal of Economic Literature, 55(3), 789-865.

Blumer, H. (1958). Race prejudice as a sense of group position. Pacific Sociological Review, 1, 37.

Budig, M. J., \& England, P. (2001). The wage penalty for motherhood. American Sociological Review, 66(2), 204-225.

Budig, M. J., \& Hodges, M. J. (2010). Differences in disadvantage: Variation in the motherhood 
penalty across white women's earnings distribution. American Sociological Review, 75(5), 705-728.

Byron, R. A. (2010). Discrimination, complexity, and the public/private sector question. Work and Occupations, 37(4), 435-475.

Charles, M. (2011). A world of difference: International trends in women's economic status. Annual Review of Sociology, 37, 355-371.

Correll, S. J., Benard, S., \& Paik, I. (2007). Getting a job: Is there a motherhood penalty? American Journal of Sociology, 112(5), 1297-1338.

DiPrete, T. A., \& Buchmann, C. (2013). The rise of women: The growing gender gap in education and what it means for American schools. New York: The Russell Sage Foundation.

England, P. (2010). The gender revolution: Uneven and stalled. Gender \& Society, 24(2), 149-166.

England, P., Farkas, G., Kilbourne, B. S., \& Dou, T. (1988). Explaining occupational sex segregation and wages: Findings from a model with fixed effects. American Sociological Review, 53(4), 544-558.

Fiske, S. T. (1998). Stereotyping, prejudice, and discrimination. In D. T. Gilbert, S. T. Fiske, \& G. Lindzey (Eds.), The Handbook of social psychology (pp. 357-411). New York: McGraw-Hill.

Goldin, C. (2006). The quiet revolution that transformed women's employment, education, and family. American Economic Review, 96(2), 1-21.

Goldin, C. (2014). A grand gender convergence: Its last chapter. American Economic Review, 104(4), 1091-1119.

Granovetter, Mark. (1985). Economic action and social structure: The problem of embeddedness. American Journal of Sociology, 91(3), 481-510.

He, G., \& Wu, X. (2017). Marketization, occupational segregation, and gender earnings inequality in urban China. Social Science Research, 65, 96-111.

He, G., \& Wu, X. (2018). Dynamics of the gender earnings inequality in reform-era Urban China. Work, Employment and Society, 32(4), 726-746.

Hoffnar, E., \& Greene, M. (1996). Gender discrimination in the public and private sectors: A sample selectivity approach. Journal of Socio-Economics, 25(1), 105-114.

Human Rights Watch. (2018). "Only men need apply”: Gender discrimination in job advertisements in China.

Ji, Y., Wu, X., Sun, S., \& He, G. (2017). Unequal care, unequal work: Toward a more 
comprehensive understanding of gender inequality in post-reform urban China. Sex Roles, 77(11-12): 765-778.

Kidd, M. P., \& Meng, X. (2001). The Chinese state enterprise sector: Labour market reform and the impact on male-female wage structure. Asian Economic Journal, 15(4), 405-423.

Kuhn, P., \& Shen, K. (2013). Gender discrimination in job ads: Evidence from China. The Quarterly Journal of Economics, 128(1), 287-336.

Lai, Y.-C., \& Masters, S. (2005). The effects of mandatory maternity and pregnancy benefits on women's wages and employment in Taiwan, 1984-1996. Industrial and Labor Relations Review, 58(2), 274-281.

Leasher, M. K., \& Miller, C. E. (2012). Discrimination across the sectors: A comparison of discrimination trends in private and public organizations. Public Personnel Management, 41(2), 281-326.

Li, C., \& Li, S. (2008). Rising gender income gap and its dynamics in China: Market competition or sex discrimination? Sociological Studies, 2, 94-117 (In Chinese).

Li, Y., \& Zhang, S. (eds). (2010). A Study of Gender Discrimination in the Workplace in China. Beijing: China Social Sciences Press (In Chinese).

Liu, P., Meng, X., \& Zhang, J. (2000). Sectoral gender wage differentials and discrimination in the transitional Chinese economy. Journal of Population Economics, 13(2), 331-352.

Mandel, H., \& Semyonov, M. (2014). Gender pay gap and employment sector: Sources of earnings disparities in the United States, 1970-2010. Demography, 51(5), 1597-1618.

Mari, G., \& Luijkx, R. 2020. Gender, parenthood, and hiring intentions in sex-typical jobs: Insights from a survey experiment. Research in Social Stratification and Mobility, 65, 100464.

Maurer-Fazio, M., \& Hughes, J. (2002). The effects of market liberalization on the relative earnings of Chinese women. Journal of Comparative Economics, 30(4), 709-731.

Maurer-Fazio, M., Rawski, T. G., \& Zhang, W. (1999). Inequality in the rewards for holding up half the sky: Gender wage gaps in China's urban labour market, 1988-1994. The China Journal, 41, 55-88.

McCall, J. J. (1972). The simple mathematics of information, job search, and prejudice. In A. H. Pascal (Eds.), Racial discrimination in economic life (pp. 205-224). Lexington, MA: D.C. Health.

Mincer, J., \& Polachek, S. (1974). Family investments in human capital: Earnings of women. 
Journal of Political Economy, 82(2), S76-S108.

National Bureau of Statistics. (2003). China Population Statistics Yearbook. Beijing: China Statistics Press (in Chinese).

National Bureau of Statistics. (2004). China Population Statistics Yearbook. Beijing: China Statistics Press (in Chinese).

National Bureau of Statistics. (2005). China Population Statistics Yearbook. Beijing: China Statistics Press (in Chinese).

National Bureau of Statistics. (2006). China Population Statistics Yearbook. Beijing: China Statistics Press (in Chinese).

National Bureau of Statistics. (2011). China Statistical Yearbook. Beijing: China Statistical Press (in Chinese).

OECD. (2017). The Pursuit of Gender Equality: An Uphill Battle. Paris: OECD Publishing. http://dx.doi.org/10.1787/9789264281318-en.

Padavic, I., \& Reskin, B. F. (2002). Women and Men in Work. Second Edition. Thousand Oaks, CA: Pine Forge Press.

Petersen, T., \& Morgan, L. A. (1995). Separate and unequal: Occupation-establishment sex segregation and the gender wage gap. American Journal of Sociology, 101(2), 329-365.

Petersen, T, Penner, A. M., \& Hogsnes, G. (2014). From motherhood penalties to husband premia: The new challenge for gender equality and family policy, lessons from Norway. American Journal of Sociology, 119(5), 1434-1472.

Phelps, E. S. (1972). The Statistical Theory of Racism and Sexism. American Economic Review, 62(4), 659-661.

Puhani, P. A., \& Sonderhof, K. (2008). The effects of maternity leave extension on training for young women. IZA discussion papers, No. 3820, Institute for the Study of Labor (IZA), Bonn.

Rawski, T. G. (2003). Recent Developments in China's Labor Economy. Working Paper. Pittsburgh, PA: University of Pittsburgh, Department of Economics.

Raymo, J. M., Park, H., Xie, Y., \& Yeung, W. J. (2015). Marriage and family in East Asia: Continuity and change. Annual Review of Sociology, 41, 471-492.

Reskin, B. F. (2000). The proximate causes of employment discrimination. Contemporary Sociology, 29(2), 319-328.

Reskin, B. F. (2002). Rethinking employment discrimination and its remedies. In M. F. Guillen, R. 
Collins, P. England, \& M. Meyer (Eds.), The new economic sociology: Developing in an emerging field (pp. 218-244). New York, NY: The Russell Sage Foundation.

Rissing, B. A., \& Castilla, E., J. (2014). House of green cards: Statistical or preference-based inequality in the employment of foreign nationals. American Sociological Review, 79(6), 1226-1255.

Shu, X., \& Bian, Y. (2003). Market transition and gender gap in earnings in urban China. Social Forces, 81(4), 1107-1145.

Shu, X. (2005). Market transition and gender segregation in urban China. Social Science Quarterly, 86(s1), 1299-1323.

Tam, T. (1997). Sex segregation and occupational gender inequality in the United States: Devaluation of specialized training? American Journal of Sociology, 102(6), 1652-1692.

Treiman, D. J. (2009). Quantitative data analysis: Doing social research to test ideas. John Wiley \& Sons, Inc.

Tilly, C. (1998). Durable Inequality. Berkeley: University of California Press.

Van Bavel, J, Schwartz, C. R., \& Esteve, A. (2018). The reversal of the gender gap in education and its consequences for family life. Annual Review of Sociology, 44, 341-360.

Verardi, V., \& Croux, C. (2009). Robust regression in Stata. The Stata Journal, 9(3), 439-453.

Wachter, K. W. (2014). Essential Demographic Methods. Cambridge, Massachusetts: Harvard University Press.

Wang, M., \& Cai, F. (2008). Gender earnings differential in urban China. Review of Development Economics, 12(2), 442-454.

Wang, T., Lai, Y., \& Li, B. (2008). Gender income gap under redistribution and its evolution: 19952003. Sociological Studies, 2, 23-53 (in Chinese).

Wang, J., \& Xie, Y. (2015). Feeling good about the iron rice bowl: Economic sector and happiness in post-reform urban China. Social Science Research, 53, 203-217.

Woodhams, C., Lupton, B., \& Xian, H. (2009). The persistence of gender discrimination in China - Evidence from recruitment advertisements. The International Journal of Human Resource Management, 20(10), 2084-2109.

World Economic Forum. (2006). The Global Gender Gap Report. Geneva, Switzerland.

World Economic Forum. (2007). The Global Gender Gap Report. Geneva, Switzerland.

World Economic Forum. (2008). The Global Gender Gap Report. Geneva, Switzerland. 
World Economic Forum. (2009). The Global Gender Gap Report. Geneva, Switzerland. World Economic Forum. (2010). The Global Gender Gap Report. Geneva, Switzerland. World Economic Forum. (2011). The Global Gender Gap Report. Geneva, Switzerland. World Economic Forum. (2012). The Global Gender Gap Report. Geneva, Switzerland. World Economic Forum. (2013). The Global Gender Gap Report. Geneva, Switzerland. World Economic Forum. (2014). The Global Gender Gap Report. Geneva, Switzerland.

$\mathrm{Wu}, \mathrm{X}$. (2002). Work units and income inequality: The effect of market transition in urban China. Social Forces, 80(3): 1069-1099.

Wu, X. (2013). Redrawing the boundaries: Work units and social stratification in urban China. Chinese Sociological Review, 45(4), 6-28.

Wu, X. (2014). Census undertakings in China: 1953-2010. Report 14-833. Ann Arbor: Population Studies Center, University of Michigan.

$\mathrm{Wu}, \mathrm{X}$. (2019). Inequality and social stratification in postsocialist China. Annual Review of Sociology, 45, 363-382.

Wu, X., \& Song, X. (2014). Ethnic stratification amid China's economic transition: Evidence from the Xinjiang Uyghur Autonomous Region. Social Science Research, 44: 158-172.

$\mathrm{Wu}, \mathrm{Y} ., \& \mathrm{Wu}, \mathrm{X}$. (2008). A study on the sex segregation in non-agricultural occupations in China in 1982-2000. Society, 5, 128-152 (in Chinese).

Wu, Y., \& Wu, X. (2009). Occupational gender segregation and gender wage gap in urban China. Sociological Studies, 4, 88-111 (in Chinese).

Wu, Y., \& Zhou, D. (2015). Women's labor force participation in urban China, 1990-2010. Chinese Sociological Review, 47(4), 314-342.

Xie, Y., \& Wu, X. (2008). Danwei profitability and earnings inequality in three Chinese cities. The China Quarterly, 195: 558-581.

Yip, C. M., \& Wong, R. S. K. (2014). Gender-oriented statistical discrimination theory: Empirical evidence from the Hong Kong labor market. Research in Social Stratification and Mobility, 37, 43-59.

Yu, W., \& Kuo, J. C. (2017). The motherhood wage penalty by work conditions: How do occupational characteristics hinder or empower mothers? American Sociological Review, 82(4), 744-769.

Zhang, D. (2004). Marketization and gender wage differentials. Chinese Journal of Population 
Science, 1, 32-41 (in Chinese).

Zhang, J., Han, J., Liu, P., \& Zhao, Y. (2008). Trends in the gender earnings differential in urban China, 1988-2004. Industrial and Labor Relations Review, 61(2), 224-243.

Zhang, Y., Hannum E., \& Wang, M. (2008). Gender-based employment and income differences in urban China: Considering the contributions of marriage and parenthood. Social Forces, 86(4), 1529-1560.

Zhang, Z., \& Wu, X. (2017). Occupational segregation and earnings inequality: Rural migrants and local workers in urban China. Social Science Research, 61, 57-74.

Zhao, X., Zhao, Y., Chou, L., \& Leivang, B. H. (2019). Changes in gender wage differentials in China: a regression and decomposition based on the data of CHIPS 1995-2013. Economic Research-Ekonomska Istraživanja, 32(1), 3162-3182. 


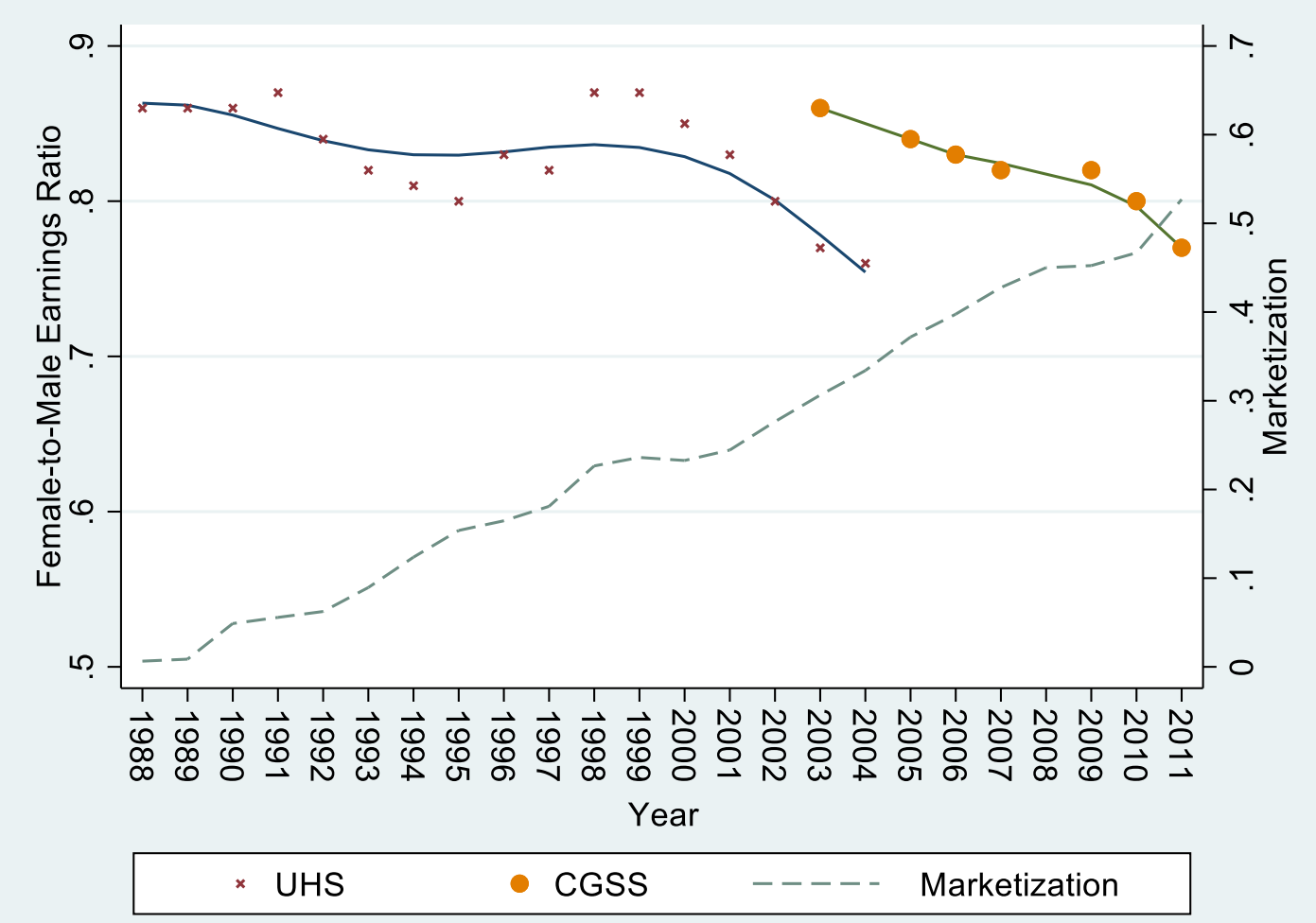

Figure 1: General trends in female-to-male earnings ratio and marketization in urban China, 1988 to 2009. Notes: The first series of data between 1988 to 2004 come from the Urban Household Surveys (UHS). Annual wage of employees aged 16-60 with urban hukou in Beijing, Guangdong, Zhejiang, Liaoning, Shannxi and Sichuan were used to calculate the gender earnings ratio (Zhang et al. 2008). The second series of data come from the Chinese General Social Survey (CGSS) 2003-2012. Hourly wage of employees aged 20-60 in urban labor market (including migrants) in mainland China (except Ningxia, Qinghai, Hainan, Tibet) were used to calculate the gender earnings ratio. 


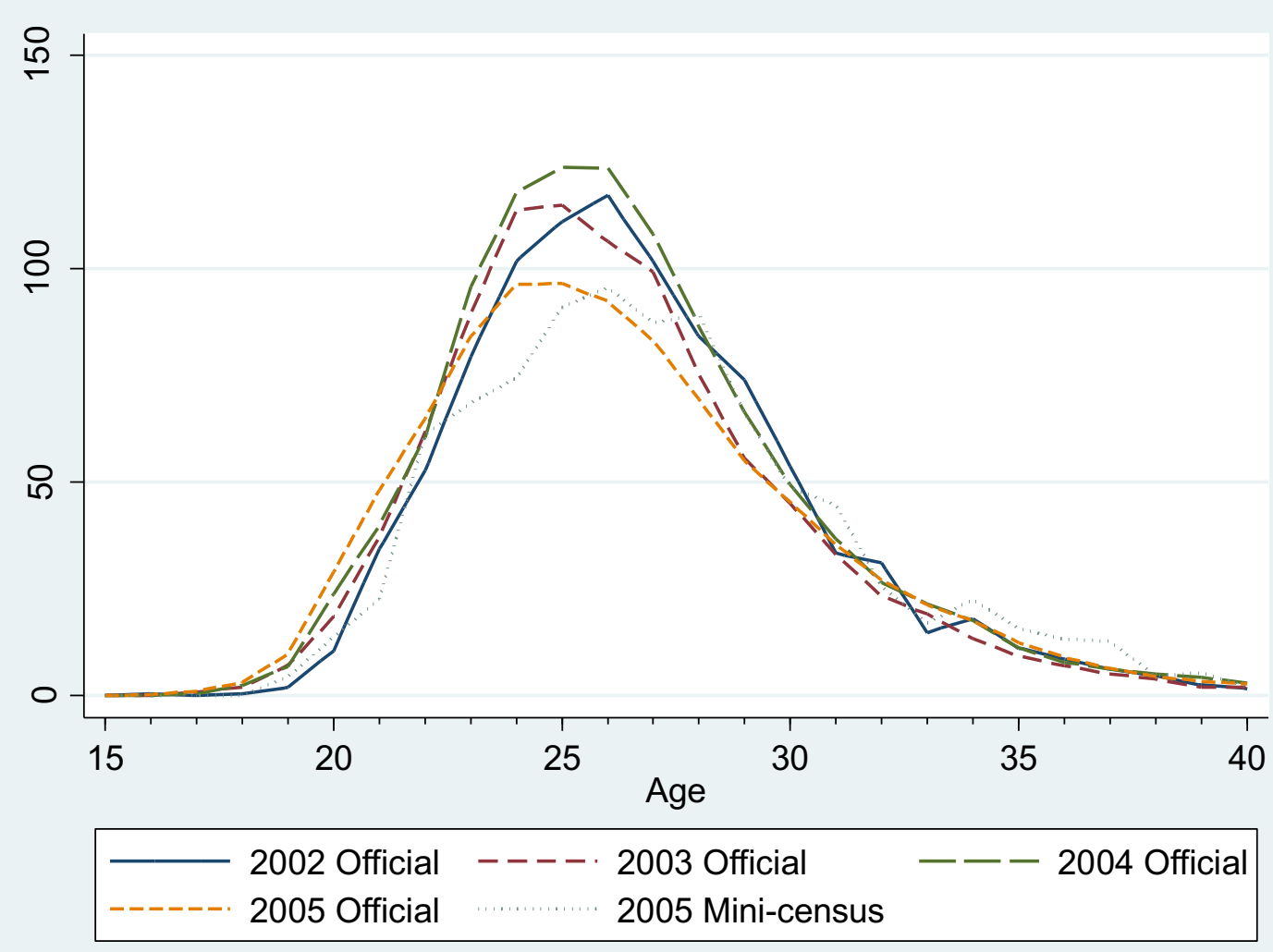

Figure 2: Period age-specific fertility rates in Chinese cities and towns, 2002-2005.

Notes: The official statistics about fertility rates in 2002 to 2005 come from the China Population Statistics Yearbook 2002 to 2005. 


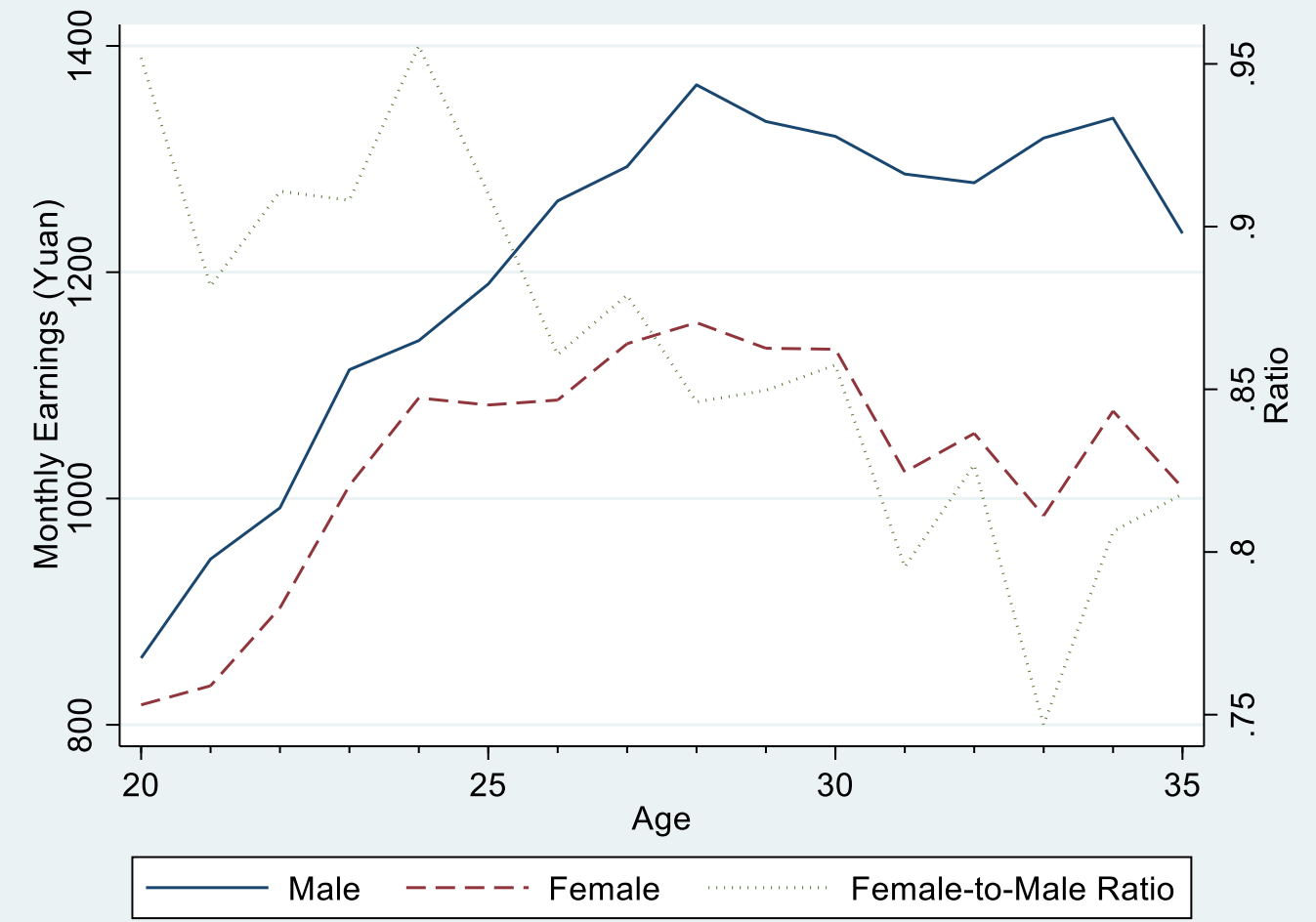

Figure 3: Average monthly earnings for male and female workers and gender earnings ratio in Urban China, 2005. 
Table 1: Descriptive statistics of employees aged 20-26 in urban China, 2005.

\begin{tabular}{lcc}
\hline & Female & Male \\
\cline { 2 - 3 } Monthly earnings (yuan) & 927.98 & 1038.91 \\
& $(627.56)$ & $(716.55)$ \\
Age-specific fertility rate (ASFR, \%) & 76.59 & 76.59 \\
& $(28.04)$ & $(28.04)$ \\
Economic sector (\%) & & \\
Government agency/public institution & 15.37 & 11.25 \\
State-owned/collective enterprises & 16.52 & 19.82 \\
Private sector & 68.12 & 68.93 \\
Years of schooling & 11.39 & 11.22 \\
Potential work experience (year) & $(2.86)$ & $(2.73)$ \\
& 5.72 & 6.02 \\
Occupation (\%) & $(3.01)$ & $(2.95)$ \\
Managerial & & \\
Professional & 0.79 & 1.21 \\
Clerical & 22.36 & 12.86 \\
Sales/service & 9.53 & 11.22 \\
Manual & 33.45 & 24.69 \\
Sex composition in occupation (\%Female) & 33.88 & 50.01 \\
Working hours last week & 0.51 & 0.37 \\
& $(0.13)$ & $(0.20)$ \\
Having no work contract (\%) & 49.54 & 50.54 \\
Married (\%) & $11.86)$ & $(11.70)$ \\
Number of children & 52.68 & 56.31 \\
Rural hukou (\%) & 32.35 & 22.62 \\
Non-han (\%) & 0.17 & 0.12 \\
N & $(0.39)$ & $(0.34)$ \\
\hline Nores: Da a & 54.35 \\
& 50.77 & 5.35 \\
& 6.06 & 4170 \\
\hline
\end{tabular}

Notes: Data are weighted. Percentages are reported for categorical variables and means are reported for continuous variables. Standard deviations of continuous variables are in parentheses. Variables with significant gender differences are indicated using bold font. 
Table 2: OLS regression results of logged monthly earnings on $A S F R$, economic sector and other covariates, urban China, 2005.

\begin{tabular}{|c|c|c|c|c|}
\hline & \multicolumn{2}{|c|}{ Female } & \multicolumn{2}{|c|}{ Male } \\
\hline & Model 1a & Model 2a & Model 1b & Model 2b \\
\hline$A S F R(\%)$ & $\begin{array}{l}-0.002^{*} \\
(0.001)\end{array}$ & $\begin{array}{c}0.000 \\
(0.001)\end{array}$ & $\begin{array}{c}0.000 \\
(0.001)\end{array}$ & $\begin{array}{c}0.000 \\
(0.001)\end{array}$ \\
\hline \multicolumn{5}{|l|}{$\begin{array}{l}\text { Economic sector } \\
\text { (ref: SOE/collective enterprise) }\end{array}$} \\
\hline Government agency/public institution & $\begin{array}{l}-0.060 \\
(0.039)\end{array}$ & $\begin{array}{l}-0.268 * * \\
(0.098)\end{array}$ & $\begin{array}{l}-0.157 * * \\
(0.050)\end{array}$ & $\begin{array}{l}-0.387^{*} \\
(0.168)\end{array}$ \\
\hline Private sector & $\begin{array}{c}0.046 \\
(0.024)\end{array}$ & $\begin{array}{l}0.189 * * \\
(0.059)\end{array}$ & $\begin{array}{c}0.014 \\
(0.025)\end{array}$ & $\begin{array}{c}0.025 \\
(0.070)\end{array}$ \\
\hline $\begin{array}{l}A S F R \times \text { Government agency/public } \\
\text { institution }\end{array}$ & & $\begin{array}{r}0.002^{*} \\
(0.001)\end{array}$ & & $\begin{array}{c}0.003 \\
(0.002)\end{array}$ \\
\hline$A S F R \times$ Private sector & & $\begin{array}{l}-0.002^{*} \\
(0.001)\end{array}$ & & $\begin{array}{l}-0.000 \\
(0.001)\end{array}$ \\
\hline Years of schooling & $\begin{array}{l}0.100^{* * *} \\
(0.011)\end{array}$ & $\begin{array}{l}0.095^{* * *} \\
(0.011)\end{array}$ & $\begin{array}{l}0.095^{* * *} \\
(0.012)\end{array}$ & $\begin{array}{l}0.093 * * * \\
(0.012)\end{array}$ \\
\hline Potential work experience & $\begin{array}{r}0.027^{*} \\
(0.012)\end{array}$ & $\begin{array}{c}0.015 \\
(0.012)\end{array}$ & $\begin{array}{c}0.015 \\
(0.015)\end{array}$ & $\begin{array}{c}0.010 \\
(0.015)\end{array}$ \\
\hline Potential work experience squared & $\begin{array}{c}0.001 \\
(0.001)\end{array}$ & $\begin{array}{l}0.002^{* *} \\
(0.001)\end{array}$ & $\begin{array}{r}0.002 * \\
(0.001)\end{array}$ & $\begin{array}{r}0.002 * \\
(0.001)\end{array}$ \\
\hline \multicolumn{5}{|l|}{ Occupation (ref: Managerial) } \\
\hline Professional & $\begin{array}{l}-0.021 \\
(0.161)\end{array}$ & $\begin{array}{l}-0.029 \\
(0.162)\end{array}$ & $\begin{array}{l}-0.211^{*} \\
(0.100)\end{array}$ & $\begin{array}{l}-0.211^{*} \\
(0.100)\end{array}$ \\
\hline Clerical & $\begin{array}{l}-0.110 \\
(0.158)\end{array}$ & $\begin{array}{l}-0.121 \\
(0.160)\end{array}$ & $\begin{array}{l}-0.325^{* *} \\
(0.100)\end{array}$ & $\begin{array}{l}-0.327^{* *} \\
(0.100)\end{array}$ \\
\hline Sales/service & $\begin{array}{l}-0.149 \\
(0.158)\end{array}$ & $\begin{array}{l}-0.157 \\
(0.159)\end{array}$ & $\begin{array}{l}-0.340 * * * \\
(0.100)\end{array}$ & $\begin{array}{l}-0.340^{* * * *} \\
(0.100)\end{array}$ \\
\hline Manual & $\begin{array}{l}-0.206 \\
(0.157)\end{array}$ & $\begin{array}{l}-0.217 \\
(0.158)\end{array}$ & $\begin{array}{l}-0.348^{* * *} \\
(0.098)\end{array}$ & $\begin{array}{l}-0.348^{* * * *} \\
(0.098)\end{array}$ \\
\hline$\%$ Female & $\begin{array}{l}-0.033 \\
(0.060)\end{array}$ & $\begin{array}{l}-0.030 \\
(0.060)\end{array}$ & $\begin{array}{l}-0.213^{* * *} \\
(0.051)\end{array}$ & $\begin{array}{l}-0.215^{* * *} \\
(0.052)\end{array}$ \\
\hline Work hours last week & $\begin{array}{c}0.001 \\
(0.001)\end{array}$ & $\begin{array}{c}0.001 \\
(0.001)\end{array}$ & $\begin{array}{c}0.002^{*} \\
(0.001)\end{array}$ & $\begin{array}{c}0.002^{*} \\
(0.001)\end{array}$ \\
\hline Having no work contract & $\begin{array}{l}-0.182^{* * *} \\
(0.015)\end{array}$ & $\begin{array}{l}-0.180^{* * *} \\
(0.015)\end{array}$ & $\begin{array}{l}-0.172 * * * \\
(0.023)\end{array}$ & $\begin{array}{l}-0.172 * * * \\
(0.023)\end{array}$ \\
\hline Married & $\begin{array}{l}-0.021 \\
(0.021)\end{array}$ & $\begin{array}{l}-0.021 \\
(0.021)\end{array}$ & $\begin{array}{c}0.072^{*} \\
(0.028)\end{array}$ & $\begin{array}{c}0.071^{*} \\
(0.028)\end{array}$ \\
\hline Number of children & $\begin{array}{l}-0.040 \\
(0.022)\end{array}$ & $\begin{array}{l}-0.042 \\
(0.022)\end{array}$ & $\begin{array}{l}-0.073^{*} \\
(0.033)\end{array}$ & $\begin{array}{l}-0.073^{*} \\
(0.033)\end{array}$ \\
\hline Rural hukou & $\begin{array}{c}0.014 \\
(0.020)\end{array}$ & $\begin{array}{c}0.014 \\
(0.020)\end{array}$ & $\begin{array}{c}0.031 \\
(0.025)\end{array}$ & $\begin{array}{c}0.031 \\
(0.025)\end{array}$ \\
\hline Non-han & $\begin{array}{c}0.021 \\
(0.031)\end{array}$ & $\begin{array}{c}0.023 \\
(0.031)\end{array}$ & $\begin{array}{l}-0.048 \\
(0.033)\end{array}$ & $\begin{array}{l}-0.047 \\
(0.033)\end{array}$ \\
\hline Industry dummies & Yes & Yes & Yes & Yes \\
\hline Province dummies & Yes & Yes & Yes & Yes \\
\hline Constant & $5.923 * * *$ & $5.890 * * *$ & $6.087 * * *$ & $6.126 * * *$ \\
\hline
\end{tabular}




\begin{tabular}{lrrrr} 
& $(0.239)$ & $(0.245)$ & $(0.220)$ & $(0.222)$ \\
$\mathrm{R}^{2}$ & 0.408 & 0.411 & 0.294 & 0.294 \\
$\mathrm{~N}$ & 4449 & 4449 & 4170 & 4170 \\
\hline
\end{tabular}

Notes: Data are weighted. Standard errors are in parentheses.

*** $p<0.001, * * p<0.01, * p<0.05$ (two-tailed tests). 
Table 3: Coefficients of period $A S F R$ on average and in each economic sector among subgroups of female workers

\begin{tabular}{|c|c|c|c|c|c|c|c|c|}
\hline & \multicolumn{3}{|c|}{ Work experience } & \multicolumn{2}{|c|}{ Motherhood status } & \multicolumn{3}{|c|}{ Occupation } \\
\hline & $\begin{array}{c}<=3 \\
\text { years }\end{array}$ & $\begin{array}{r}\text { 4-5 } \\
\text { years }\end{array}$ & $\begin{array}{l}6 \text { years } \\
\text { and } \\
\text { more }\end{array}$ & $\begin{array}{l}\text { Childless } \\
\text { women }\end{array}$ & Mothers & $\begin{array}{l}\text { Managerial } \\
\text { and } \\
\text { professional }\end{array}$ & $\begin{array}{l}\text { Clerk, } \\
\text { sales, } \\
\text { service }\end{array}$ & Manual \\
\hline$A S F R$ on average (\%o) & $\begin{array}{l}-0.005^{*} \\
(0.002)\end{array}$ & $\begin{array}{l}-0.004^{* *} \\
(0.001)\end{array}$ & $\begin{array}{l}-0.002 * \\
(0.001)\end{array}$ & $\begin{array}{l}-0.002 * * \\
(0.001)\end{array}$ & $\begin{array}{c}0.002 \\
(0.002)\end{array}$ & $\begin{array}{c}0.001 \\
(0.002)\end{array}$ & $\begin{array}{l}-0.002 * \\
(0.001)\end{array}$ & $\begin{array}{l}-0.000 \\
(0.001)\end{array}$ \\
\hline$A S F R$ in Government agency/public Institution (\%) & $\begin{array}{l}-0.001 \\
(0.002)\end{array}$ & $\begin{array}{l}-0.008 \\
(0.005)\end{array}$ & $\begin{array}{l}-0.001 \\
(0.002)\end{array}$ & $\begin{array}{c}0.002 \\
(0.001)\end{array}$ & $\begin{array}{c}0.002 \\
(0.004)\end{array}$ & $\begin{array}{c}0.002 \\
(0.002)\end{array}$ & $\begin{array}{c}0.004 \\
(0.003)\end{array}$ & $\begin{array}{c}0.003 \\
(0.004)\end{array}$ \\
\hline ASFR in SOE/collective enterprise (\%) & $\begin{array}{l}-0.003 \\
(0.002)\end{array}$ & $\begin{array}{l}-0.004 \\
(0.002)\end{array}$ & $\begin{array}{l}-0.002 \\
(0.001)\end{array}$ & $\begin{array}{l}-0.000 \\
(0.001)\end{array}$ & $\begin{array}{c}0.005 \\
(0.004)\end{array}$ & $\begin{array}{c}0.002 \\
(0.002)\end{array}$ & $\begin{array}{l}-0.001 \\
(0.001)\end{array}$ & $\begin{array}{c}0.000 \\
(0.002)\end{array}$ \\
\hline$A S F R$ in the private sector $(\%)$ & $\begin{array}{l}-0.006^{* *} \\
(0.002)\end{array}$ & $\begin{array}{l}-0.005^{* *} \\
(0.001)\end{array}$ & $\begin{array}{l}-0.002 * \\
(0.001)\end{array}$ & $\begin{array}{l}-0.002 * * \\
(0.001)\end{array}$ & $\begin{array}{c}0.001 \\
(0.002)\end{array}$ & $\begin{array}{l}-0.001 \\
(0.002)\end{array}$ & $\begin{array}{l}-0.002 * \\
(0.001)\end{array}$ & $\begin{array}{l}-0.000 \\
(0.001)\end{array}$ \\
\hline $\mathrm{N}$ & 1120 & 1044 & 2285 & 3732 & 717 & 969 & 1946 & 1534 \\
\hline
\end{tabular}

Notes: Data are weighted. Standard errors are in parentheses.

$* * * p<0.001, * * p<0.01, * p<0.05$ (two-tailed tests). 
Table A1: OLS regression results of logged monthly earnings using alternative measures of period $A S F R$ (official statistics at the national level).

\begin{tabular}{|c|c|c|c|c|}
\hline & \multicolumn{2}{|c|}{ Female } & \multicolumn{2}{|c|}{ Male } \\
\hline & Model 1a & Model 2a & Model 1b & Model 2b \\
\hline & & & & \\
\hline $\begin{array}{l}\text { Panel A } \\
A_{S F R} 2005(\%)\end{array}$ & $\begin{array}{l}-0.002 * * \\
(0.001)\end{array}$ & $\begin{array}{l}-0.000 \\
(0.001)\end{array}$ & $\begin{array}{l}-0.000 \\
(0.001)\end{array}$ & $\begin{array}{l}-0.000 \\
(0.001)\end{array}$ \\
\hline \multicolumn{5}{|l|}{$\begin{array}{l}\text { Economic sector } \\
\text { (ref: SOE/collective enterprise) }\end{array}$} \\
\hline Government agency/ public institution & $\begin{array}{l}-0.061 \\
(0.039)\end{array}$ & $\begin{array}{l}-0.285 \\
(0.148)\end{array}$ & $\begin{array}{l}-0.156^{* *} \\
(0.050)\end{array}$ & $\begin{array}{l}-0.212 \\
(0.258)\end{array}$ \\
\hline Private sector & $\begin{array}{l}0.047^{*} \\
(0.024)\end{array}$ & $\begin{array}{l}0.213^{*} \\
(0.085)\end{array}$ & $\begin{array}{c}0.014 \\
(0.025)\end{array}$ & $\begin{array}{c}0.049 \\
(0.098)\end{array}$ \\
\hline $\begin{array}{l}A S F R_{2005} \times \text { government agency/ } \\
\text { public institution }\end{array}$ & & $\begin{array}{c}0.002 \\
(0.002)\end{array}$ & & $\begin{array}{c}0.001 \\
(0.003)\end{array}$ \\
\hline$A S F R_{2005} \times$ private sector & & $\begin{array}{l}-0.002 * \\
(0.001) \\
\end{array}$ & & $\begin{array}{l}-0.000 \\
(0.001) \\
\end{array}$ \\
\hline \multicolumn{5}{|l|}{ Panel B } \\
\hline$A S F R_{2004}(\%)$ & $\begin{array}{l}-0.002 * \\
(0.001)\end{array}$ & $\begin{array}{l}-0.000 \\
(0.001)\end{array}$ & $\begin{array}{l}-0.001 \\
(0.001)\end{array}$ & $\begin{array}{l}-0.001 \\
(0.001)\end{array}$ \\
\hline \multicolumn{5}{|l|}{$\begin{array}{l}\text { Economic sector } \\
\text { (ref: SOE/collective enterprise) }\end{array}$} \\
\hline Government agency/ public institution & $\begin{array}{l}-0.060 \\
(0.039)\end{array}$ & $\begin{array}{l}-0.206^{*} \\
(0.104)\end{array}$ & $\begin{array}{l}-0.156^{* *} \\
(0.050)\end{array}$ & $\begin{array}{l}-0.340^{*} \\
(0.147)\end{array}$ \\
\hline Private sector & $\begin{array}{l}0.048 * \\
(0.024)\end{array}$ & $\begin{array}{l}0.172 * * \\
(0.061)\end{array}$ & $\begin{array}{c}0.014 \\
(0.025)\end{array}$ & $\begin{array}{c}0.014 \\
(0.069)\end{array}$ \\
\hline $\begin{array}{l}A S F R_{2004} \times \text { government agency/ } \\
\text { public institution }\end{array}$ & & $\begin{array}{c}0.001 \\
(0.001)\end{array}$ & & $\begin{array}{c}0.002 \\
(0.001)\end{array}$ \\
\hline$A S F R_{2004} \times$ private sector & & $\begin{array}{l}-0.001 * \\
(0.001)\end{array}$ & & $\begin{array}{l}-0.000 \\
(0.001)\end{array}$ \\
\hline \multicolumn{5}{|l|}{ Panel C } \\
\hline$A S F R_{2003}(\%)$ & $\begin{array}{l}-0.001 * * \\
(0.000)\end{array}$ & $\begin{array}{l}-0.000 \\
(0.001)\end{array}$ & $\begin{array}{l}-0.000 \\
(0.001)\end{array}$ & $\begin{array}{l}-0.000 \\
(0.001)\end{array}$ \\
\hline \multicolumn{5}{|l|}{$\begin{array}{l}\text { Economic sector } \\
\text { (ref: SOE/collective enterprise) }\end{array}$} \\
\hline Government agency/ public institution & $\begin{array}{l}-0.061 \\
(0.039)\end{array}$ & $\begin{array}{l}-0.220 * \\
(0.107)\end{array}$ & $\begin{array}{l}-0.156^{* *} \\
(0.050)\end{array}$ & $\begin{array}{l}-0.268 \\
(0.165)\end{array}$ \\
\hline Private sector & $\begin{array}{c}0.047^{*} \\
(0.024)\end{array}$ & $\begin{array}{l}0.171 * * \\
(0.062)\end{array}$ & $\begin{array}{c}0.014 \\
(0.025)\end{array}$ & $\begin{array}{c}0.028 \\
(0.071)\end{array}$ \\
\hline $\begin{array}{l}A S F R_{2003} \times \text { government agency/ } \\
\text { public institution }\end{array}$ & & $\begin{array}{c}0.001 \\
(0.001)\end{array}$ & & $\begin{array}{c}0.001 \\
(0.001)\end{array}$ \\
\hline$A S F R_{2003} \times$ private sector & & $\begin{array}{l}-0.001 * \\
(0.001)\end{array}$ & & $\begin{array}{l}-0.000 \\
(0.001)\end{array}$ \\
\hline Panel D & & & & \\
\hline$A S F R_{2002}(\%)$ & $\begin{array}{l}-0.001 * \\
(0.001)\end{array}$ & $\begin{array}{l}-0.000 \\
(0.001)\end{array}$ & $\begin{array}{l}-0.001 \\
(0.001)\end{array}$ & $\begin{array}{l}-0.001 \\
(0.001)\end{array}$ \\
\hline $\begin{array}{l}\text { Economic sector } \\
\text { (ref: SOE/collective enterprise) }\end{array}$ & & & & \\
\hline Government agency/ public institution & $\begin{array}{l}-0.060 \\
(0.039)\end{array}$ & $\begin{array}{l}-0.186^{*} \\
(0.091)\end{array}$ & $\begin{array}{l}-0.156^{* *} \\
(0.050)\end{array}$ & $\begin{array}{l}-0.302^{*} \\
(0.130)\end{array}$ \\
\hline Private sector & $\begin{array}{l}0.048 * \\
(0.024)\end{array}$ & $\begin{array}{l}0.153^{* *} \\
(0.053)\end{array}$ & $\begin{array}{c}0.014 \\
(0.025)\end{array}$ & $\begin{array}{c}0.016 \\
(0.060)\end{array}$ \\
\hline
\end{tabular}


$A S F R_{2002} \times$ government agency/ $\quad 0.001$

public institution

$(0.001)$

0.001

$A S F R_{2002} \times$ private sector

$-0.001 *$

$(0.001)$

(0.001)

$-0.000$

4449

(0.001)

4449

4170

4170

Notes: Data are weighted. Coefficients of other covariates (same as those in Table 2) are omitted. Standard errors are in parentheses.

$* * * p<0.001, * * p<0.01, * p<0.05$ (two-tailed tests). 
Table A2: OLS regression results of logged monthly earnings using different age ranges.

20-24

$\operatorname{ASFR}(\%)$

Economic sector

(ref: SOE/collective enterprise)

Government agency/ public institution

Private sector

$A S F R \times$ government agency/

public institution

$A S F R \times$ private sector

$\mathrm{N}$

20-25

ASFR (\%)

Economic sector

(ref: SOE/collective enterprise)

Government agency/ public institution

Private sector

$A S F R \times$ government agency/

public institution

$A S F R \times$ private sector

$\mathrm{N}$

20-27

ASFR (\%)

Economic sector

(ref: SOE/collective enterprise)

Government agency/ public institution

Private sector

$A S F R \times$ government agency/

public institution

$A S F R \times$ private sector

$\mathrm{N}$

20-28

ASFR (\%)

Economic sector

(ref: SOE/collective enterprise)

Government agency/ public institution

Private sector

\begin{tabular}{lc}
\multicolumn{2}{c}{ Female } \\
\hline Model 1a & Model 2a \\
\hline
\end{tabular}

\begin{tabular}{lc}
\multicolumn{2}{c}{ Male } \\
\hline Model 1b & Model 2b \\
\hline
\end{tabular}

$\begin{array}{lccc}-0.001 & 0.000 & 0.001 & 0.001 \\ (0.001) & (0.001) & (0.001) & (0.001)\end{array}$

$$
-0.040
$$

$(0.045)$

0.044

$(0.026)$

$-0.320 * *$

$(0.108)$

$0.174 * *$

(0.063)

$0.004 *$

$(0.001)$

$-0.002 *$

$(0.001)$

3110

3110

\section{$-0.001$}

$(0.001)$

0.000

(0.001)

$-0.176^{*}$

$-0.338$

$(0.076)$

(0.186)

$-0.031$

0.045

$(0.029)$

(0.076)

0.002

(0.002)

$-0.001$

(0.001)

2837

\begin{tabular}{cc}
2837 & 2837 \\
\hline 0.000 & 0.001 \\
$(0.001)$ & $(0.001)$
\end{tabular}

\section{$-0.046$}

$-0.255^{*}$

(0.102)

$-0.175 * *$

-0.329 *

$(0.044)$

0.198 **

(0.058)

(0.168)

$(0.025)$

$(0.061)$

$0.002 *$

(0.001)

$-0.002 * *$

0.002

0.015

(0.027)

(0.072)

0.002

(0.002)

(0.001)

$-0.000$

(0.001)

$-0.0$

3751

3751

$-0.001^{* *}$

$-0.000$

$(0.000)$

(0.001)

(0.001)

0.000

(0.001)

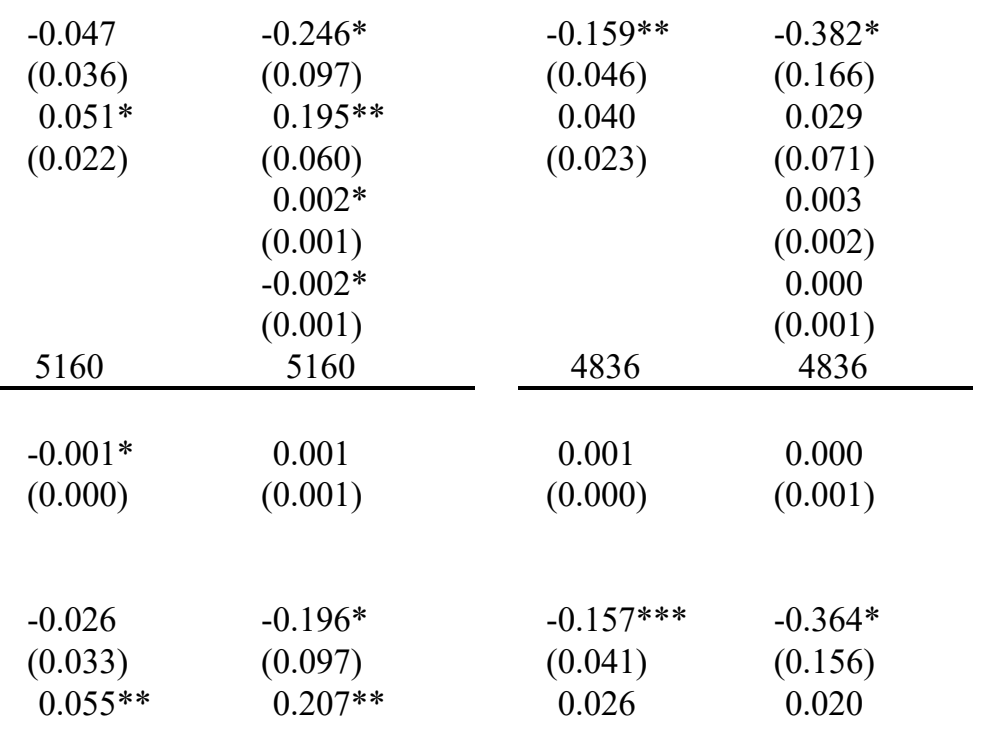




\begin{tabular}{|c|c|c|c|c|}
\hline & $(0.021)$ & $(0.060)$ & $(0.022)$ & $(0.070)$ \\
\hline$A S F R \times$ government agency $/$ & & 0.002 & & 0.002 \\
\hline public institution & & $(0.001)$ & & $(0.002)$ \\
\hline$A S F R \times$ private sector & & $\begin{array}{l}-0.002 * \\
(0.001)\end{array}$ & & $\begin{array}{c}0.000 \\
(0.001)\end{array}$ \\
\hline $\mathrm{N}$ & 5790 & 5790 & 5478 & 5478 \\
\hline
\end{tabular}

Notes: Data are weighted. Coefficients of other covariates (same as those in Table 2) are omitted. Standard errors are in parentheses.

$* * * p<0.001, * * p<0.01, * p<0.05$ (two-tailed tests). 
Table A3: OLS regression results of logged monthly earnings on $A S F R$, economic sector, and other covariates net of occupation fixed effects.

\begin{tabular}{|c|c|c|c|c|}
\hline & \multicolumn{2}{|c|}{ Female } & \multicolumn{2}{|c|}{ Male } \\
\hline & Model 1a & Model 2a & Model 1b & Model 2b \\
\hline$A S F R(\%)$ & $\begin{array}{l}-0.002 * * \\
(0.001)\end{array}$ & $\begin{array}{l}-0.000 \\
(0.001)\end{array}$ & $\begin{array}{c}0.000 \\
(0.001)\end{array}$ & $\begin{array}{l}0.000 \\
(0.001)\end{array}$ \\
\hline $\begin{array}{l}\text { Economic sector } \\
\text { (ref: SOE/collective enterprise) }\end{array}$ & & & & \\
\hline Government agency/public institution & $\begin{array}{l}-0.028 \\
(0.041)\end{array}$ & $\begin{array}{l}-0.294 * * \\
(0.102)\end{array}$ & $\begin{array}{l}-0.110^{*} \\
(0.050)\end{array}$ & $\begin{array}{l}-0.376^{*} \\
(0.169)\end{array}$ \\
\hline Private sector & $\begin{array}{c}0.037 \\
(0.023)\end{array}$ & $\begin{array}{l}0.164 * * \\
(0.059)\end{array}$ & $\begin{array}{c}0.010 \\
(0.025)\end{array}$ & $\begin{array}{c}0.011 \\
(0.073)\end{array}$ \\
\hline$A S F R \times$ Government agency/public institution & & $\begin{array}{l}0.003 * * \\
(0.001)\end{array}$ & & $\begin{array}{c}0.003 \\
(0.002)\end{array}$ \\
\hline$A S F R \times$ Private sector & & $\begin{array}{l}-0.002 * \\
(0.001)\end{array}$ & & $\begin{array}{l}-0.000 \\
(0.001)\end{array}$ \\
\hline Other covariates & YES & YES & YES & YES \\
\hline Occupation fixed effects & YES & YES & YES & YES \\
\hline Industry dummies & YES & YES & YES & YES \\
\hline Province dummies & YES & YES & YES & YES \\
\hline Constant & $\begin{array}{l}5.694 * * * \\
(0.183)\end{array}$ & $\begin{array}{l}5.668 * * * \\
(0.190)\end{array}$ & $\begin{array}{l}6.146^{* * *} \\
(0.287)\end{array}$ & $\begin{array}{l}6.198 * * * \\
(0.290)\end{array}$ \\
\hline $\mathrm{R}^{2}$ & 0.431 & 0.435 & 0.329 & 0.330 \\
\hline $\mathrm{N}$ & 4449 & 4449 & 4170 & 4170 \\
\hline
\end{tabular}

Notes: Data are weighted. Standard errors are in parentheses. \%Female is not included as we control for occupation fixed effects in the regression models. Other covariates are the same as those in Table 2.

$* * * p<0.001, * * p<0.01, * p<0.05$ (two-tailed tests). 